\title{
Aging and Options to Halt Declining Immunity to Virus Infections
}

\author{
Miguel Ángel Palacios-Pedrero, Albert D. M. E. Osterhaus, Tanja Becker, Husni Elbahesh, \\ Guus F. Rimmelzwaan ${ }^{*}$ and Giulietta Saletti ${ }^{*}$
}

Research Center for Emerging Infections and Zoonoses, University of Veterinary Medicine Hannover, Hannover, Germany

OPEN ACCESS

Edited by:

Mario (Mago) Clerici,

University of Milan, Italy

Reviewed by:

Brandt D. Pence,

University of Memphis,

United States

Calogero Caruso,

University of Palermo, Italy

*Correspondence:

Guus F. Rimmelzwaan

Guus.Rimmelzwaan@tiho-

hannover.de

Giulietta Saletti

Giulietta.Saletti@tiho-hannover.de

Specialty section:

This article was submitted to

Viral Immunology,

a section of the journal

Frontiers in Immunology

Received: 16 March 2021 Accepted: 26 April 2021

Published: 12 May 2021

Citation:

Palacios-Pedrero MÁ, Osterhaus ADME, Becker T, Elbahesh H, Rimmelzwaan GF and Saletti G (2021) Aging and

Options to Halt Declining

Immunity to Virus Infections.

Front. Immunol. 12:681449. doi: 10.3389/fimmu.2021.681449
Immunosenescence is a process associated with aging that leads to dysregulation of cells of innate and adaptive immunity, which may become dysfunctional. Consequently, older adults show increased severity of viral and bacterial infections and impaired responses to vaccinations. A better understanding of the process of immunosenescence will aid the development of novel strategies to boost the immune system in older adults. In this review, we focus on major alterations of the immune system triggered by aging, and address the effect of chronic viral infections, effectiveness of vaccination of older adults and strategies to improve immune function in this vulnerable age group.

Keywords: aging, cell mediated immunity, virus infections, vaccine, immunosenescence

\section{INTRODUCTION}

Life expectancy is currently higher than ever and by 2050 the number of individuals over 65 years of age is estimated to be more than 1.6 billion worldwide (https://www.who.int/news-room/factsheets/detail/ageing-and-health). Aging is associated with progressive changes involving all organ systems including the immune system, collectively affecting the ability to mount protective immune responses to various infectious pathogens and to vaccination (1-9). Therefore, age-related diseases and conditions are of major public health concern and should prompt the development of more effective therapies and vaccines to prevent or mitigate the impact of infectious diseases that are a major cause of morbidity and mortality in older adults (10-13). For instance, the recent outbreak of COVID-19 caused by SARS CoV-2 has highlighted the increased severity of this virus infection in older adults, resulting in disproportionally high morbidity and mortality rates (14-19).

The term "immunosenescence" refers to alterations and dysregulation of the immune system that take place during aging. It is a multifaceted, biological process causing a progressive malfunctioning of cells of innate and adaptive immunity. Changes in both composition and function of immune cells characterized by up- or down-regulation of surface markers, defects in cell signaling and alterations of cell populations are hallmarks of immunosenescence. On the one hand, genetic background, microbiome, diet, co-morbidities and/or environmental factors are thought to play a role in the aging process $(20,21)$. Immunosenescence has also been reported in some animal species including non-human primates and dogs $(22-24)$. On the other hand, it should be considered that: (i) many older adults remain healthy until advanced age ( $>90$ years of age); (ii) in some cases "dysfunctional" immune cells can function properly when stimulated adequately, e.g., with the use of vaccines designed for use in older people; (iii) altered response not always translates into being harmful $(25,26)$. 
The innate immune system plays a key role as the first line of defense against pathogens and promotes the adaptive immune system to generate long-lasting protective immunity. In case of vaccination, the functionality of innate immune cells at the site of administration (e.g., macrophages, dendritic cells, neutrophils) is of importance and largely dictates the outcome of vaccination. In older adults, it has been reported that antigen processing and presentation capacities are reduced and neutrophil cytokine production is altered, leading to dysfunctional chemotaxis and activation of other immune cells (27-33). Upon infection or vaccination, a small number of naive $\mathrm{CD} 4^{+}$and $\mathrm{CD} 8^{+} \mathrm{T}$ cells recognize a cognate peptide/MHC complex presented by antigen presenting cells, which undergo activation, proliferation and differentiation into effector cells. After the contraction phase, the majority of the effector cells (90-95\%) die by apoptosis and only a small fraction of the $\mathrm{CD}^{+}$and $\mathrm{CD}^{+} \mathrm{T}$ cell effector population differentiate into memory cells (34-36). These cells are responsible for maintaining long-term immunity and protective recall responses. Older individuals experience a decrease in the number of naive $T$ cells due to reduced hematopoiesis and thymus involution, which impairs the response to novel antigens, including vaccine antigens (37-41). Nonetheless, naive $\mathrm{T}$ cells from individuals older than 70 years still exhibit highly diverse $\mathrm{T}$ cell receptor (TCR) specificities, albeit reduced compared to those of younger adults $(38,40,42)$. Furthermore, immunosenescent $\mathrm{T}$ cells are characterized by an impaired proliferation rate, resistance to apoptosis, downregulation of costimulatory surface molecules (e.g., CD27 and CD28), telomere shortening and expression of KLRG-1 and CD57 (43-55). Under normal circumstances, the fine-controlled balance between proinflammatory and anti-inflammatory cytokines maintains the physiologic function of inflammation. In older people, dysregulation of cytokine production with a progressive tendency toward a proinflammatory phenotype (e.g., IL-6, IL-15, IFN- $\gamma$ ), is believed to play a key role in the inability to control systemic inflammation. This chronic low-grade of uncontrolled inflammation is defined as "inflammaging" (56-64). Recent studies have shown that persistence of chronic inflammation is associated with various environmental and metabolic factors (e.g., diet, nutrition and gut microbiota) (65-67). Pro-inflammatory cytokines are also secreted in response to oxidative stress, DNA damage and autophagy [reviewed elsewhere $(68,69)]$. The processes of immunosenescence and inflammaging are intertwined with each other. On the one hand, senescent cells, which accumulate during aging, are characterized by a pro-inflammatory cytokine secretion pattern, leading to inflammaging. On the other hand, an increase of such inflammatory mediators drives altered adaptive immune responses, contributing to immunosenescence. Both processes are therefore involved in a vicious cycle that impairs functioning of the immune system in older adults (70-72). In addition, chronic infections (e.g., caused by cytomegalovirus) contribute to the enhancement of both, immunosenescence and inflammaging. Such pathogens trigger a low but continuous inflammatory response in the host, as well as a clonal expansion of differentiated/memory $\mathrm{T}$ cells at the cost of naive T cell compartment, contributing to an impaired immune response to novel pathogens (73-78).

The second arm of the adaptive immune response is mediated by humoral immunity. Humoral immunity is a key correlate of protection against infectious pathogens and the induction of specific antibodies and the development of specific B cell memory are pivotal to provide protection against reinfection and contribute to the success of vaccination. Aging has a profound impact on diversity of the B cell repertoire. Impaired somatic hypermutation and isotype switching, together with a reduction in the number of plasma cells, affect the magnitude and quality of the antibody response induced by infection or vaccination $(41,79-82)$.

Aging also has a major impact on the severity of viral and bacterial infections, resulting in a more severe course and often fatal outcome in the older population. Furthermore, effectiveness and longevity of vaccination, the main preventive measure against infections, are gradually reduced in the aging population. Certain viruses can establish a low level of viral replication and cause persistent and often latent infections. In immunosenescent adults, these viruses can reactivate and cause a severe infection that can lead to recurrent disease of increasing severity. Varicella zoster virus (VZV) infection is a notable example of this. VZV, an $\alpha$-herpesvirus, usually causes infections during childhood (chickenpox) and then becomes persistent and latent. Virus reactivation leads to shingles, also known as herpes zoster (HZ), and possible further serious complications (83-88). Another example is the human cytomegalovirus (CMV), which is highly prevalent in adults worldwide. CMV, a $\beta$-herpesvirus, also establishes life-long latent infection and is generally considered to promote T cell immunosenescence (89-91). CMV infection leads to continuous or chronic antigen presentation, resulting in increased numbers of highly differentiated T cells with a reduced TCR repertoire (62, 92-96).

In addition, other (respiratory) viruses, such as respiratory syncytial virus (RSV) and influenza viruses (IVs), cause more severe respiratory disease with complications and mortality in older adults, especially in association of co-morbidities (97-102). Although effective influenza vaccines are available, their effectiveness is not optimal in older people. Attempts to develop more immunogenic vaccine formulations for this age category have resulted in somewhat more effective influenza vaccines (103106). In contrast, a registered RSV vaccine is still not available, although several candidate RSV vaccines are in various stages of development (107-110).

In this review, we discuss the current understanding of agerelated changes affecting immune cells and how that influences protective immune response to virus infection and vaccination. Moreover, we will give an insight into strategies that are currently used, or under development, to improve immune cell functions and vaccine efficacy in older adults.

\section{AGE-ASSOCIATED IMMUNE CELL DYSFUNCTIONS}

The immune system is complex and involves the interplay of many different cell types that collectively afford protection against infectious pathogens. Aging negatively influences the function of immune cells resulting in increased severity of infections and impaired responses upon vaccination. Although there is an increasing interest in the development of therapeutic 
and preventive strategies targeting older adults, many molecular processes leading to immunosenescence are still not fully understood. Additionally, a large body of knowledge has been obtained from mouse models; however, it is not clear to what extent this model faithfully represents the mechanisms controlling these processes in humans. Furthermore, most studies have used peripheral blood mononuclear cells (PBMCs) because of ease of accessibility, but these do not account for potential changes of cells residing in tissues. Consequently, more research is required to obtain a better understanding of immunosenescence in aging humans, which will guide the design of improved vaccines tailored for use in the aging population.

Some of the factors that are known to play a role in immunosenescence during aging include genomic instability, telomere shortening, epigenetic modifications, changes of intracellular signal pathways responsible for cell communication and dysfunction of mitochondria [reviewed elsewhere $(8,111)$ ].

Here we will focus on age-related changes of immune cells of both innate and adaptive immunity, along with those induced after infection or vaccination (Figure 1).

\section{Innate Immune System}

Dendritic cells (DCs) are critical for the induction of protective immune responses against pathogens and represent the link between innate and adaptive immunity. DCs are professional antigen-presenting cells that provide activation signals to $\mathrm{T}$ cells and are crucial for mounting a robust humoral response (112-114). DCs can be activated by various stimuli including microbes, apoptotic cells, and inflammatory cytokines. They sense pathogens at the port of entry through pattern recognition receptors (PRRs) (e.g., Toll-like receptors, C-type lectin receptors, intracytoplasmic NOD-like receptors), and then migrate to the lymphoid organs where they prime naive $\mathrm{T}$ cells and regulate $\mathrm{B}$ cell responses. DCs are comprised of two major subsets of either myeloid (mDCs; conventional/classical DC, cDC) or lymphoid origin (plasmocytoid; pDCs). mDCs regulate pro-inflammatory responses (e.g., via T-helper 1 and cytotoxic $\mathrm{T}$ lymphocyte responses) upon bacterial and viral infections, and $\mathrm{pDC}$ produce type I interferon, that can directly antagonize viral replication (115118). It has been shown that magnitude, functionality and signaling of the pDCs are reduced in older people, and that has been correlated with the increased occurrence of severe influenza virus infections in this age group $(30,119,120)$. Yet, impaired T cell proliferation and IFN- $\gamma$ secretion have been observed upon stimulation of aged pDCs with influenza virus (121). Transcriptional analyses have demonstrated that PBMCs from people over 65 years of age display a delayed and atypical response after stimulation via some Toll-like receptors (TLR4 and TLR7/8) compared to those from younger individuals ( $<40$ years old), which has a profound effect on the production of effector molecules involved in $\mathrm{T}$ cell activation and proliferation, such as IFN- $\gamma$ and TNF- $\alpha$ (122). Following TLR7/9 stimulation, pDCs of older subjects produce less type I and III interferons and display a reduced antigen presentation that impairs $\mathrm{T}$ cell activation (121). An increased level of IL- 6 and TNF- $\alpha$ secreted by "old" mDCs in response to LPS, ssRNA, and self-DNA, has been associated to alteration in signaling pathways that lead to PI3K, NF- $\mathrm{BB}$, or type I IFN responses $(123,124)$. A decreased expression and/or function of some TLRs in DCs and monocytes in older adults individuals has also been reported (125-127). Moreover, epigenetic changes (e.g., methylation or phosphorylation) induce up-regulation of immune checkpoint molecules on DCs that reduce the ability to migrate to the secondary lymphoid, leading to an impaired $\mathrm{T}$ cell activation $(114,128-132)$. The development of a robust and protective antibody response with generation of high-affinity antibodies is mediated by the ability of follicular DCs (fDCs) to capture and retain, for extended periods of time, native antigen in the $\mathrm{B}$ cell follicles within the germinal center. Studies have documented that age-related defects in the germinal center formation and reaction (e.g., retention of antigen complexes and reduced expression of the FcyRII on fDCs), have a dramatic impact on generation of humoral immunity (133).

Monocytes and tissue-resident macrophages, which can be monocyte-derived or embryo-derived, are phagocytic cells, primarily involved in the innate immune response against infectious pathogens and also involved in the maintenance of tissue homeostasis (134). Age-related defects in the macrophage/ monocyte lineage function are predominantly mediated by the dysregulation of cellular signaling, which affects antigen presentation and response to inflammatory stimuli (135-137). Macrophages are usually divided in two subsets M1 (proinflammatory) and M2 (anti-inflammatory/immune regulatory) and aging alters their polarization and function (137-139). Due to the difficulty in obtaining and studying tissue-resident macrophages and their highly diverse tissue-dependent phenotypes, it is still not completely understood which macrophages/tissue are more affected by aging (140-142). Macrophages may also contribute to the chronic inflammatory state in older adults and lead to the progression of age-associated diseases. Although no differences have been found in the number of peripheral blood monocytes in older adults compared to younger subjects, there is an agedependent upward shift in the proportion of monocyte subsets with an inflammatory profile. For example, 'non-classical' $\mathrm{CD} 14^{\text {low }} \mathrm{CD} 16^{+}$monocytes specifically increase with age and display reduced HLA-DR and CX(3)CR1 surface expression (143). Upon TLR stimulation, monocytes display age-dependent differences, both at transcriptional and functional levels, resulting in a differential expression of surface molecules and cytokine production (144). These age-related alterations have been mainly associated to impaired monocyte TLR responses, although few studies show a rather enhanced inflammatory response (125, 144-146). For example, a positive correlation was found between surface expression of B7 co-stimulatory molecules before influenza vaccination and the vaccine induced antibody response, but interestingly, this correlation was weaker for older vaccinees (147149). Furthermore, expression of MHC class II molecules was lower in aged human monocytes and mouse macrophages (150-153). Moreover, aged human monocytes have shortened telomeres, reduced phagocytic capacity and high level of intracellular TNF$\alpha$ (154).

Neutrophils are phagocytic cells that migrate from blood to infected tissues and rapidly respond to invading pathogens by 


\section{Innate immune system}

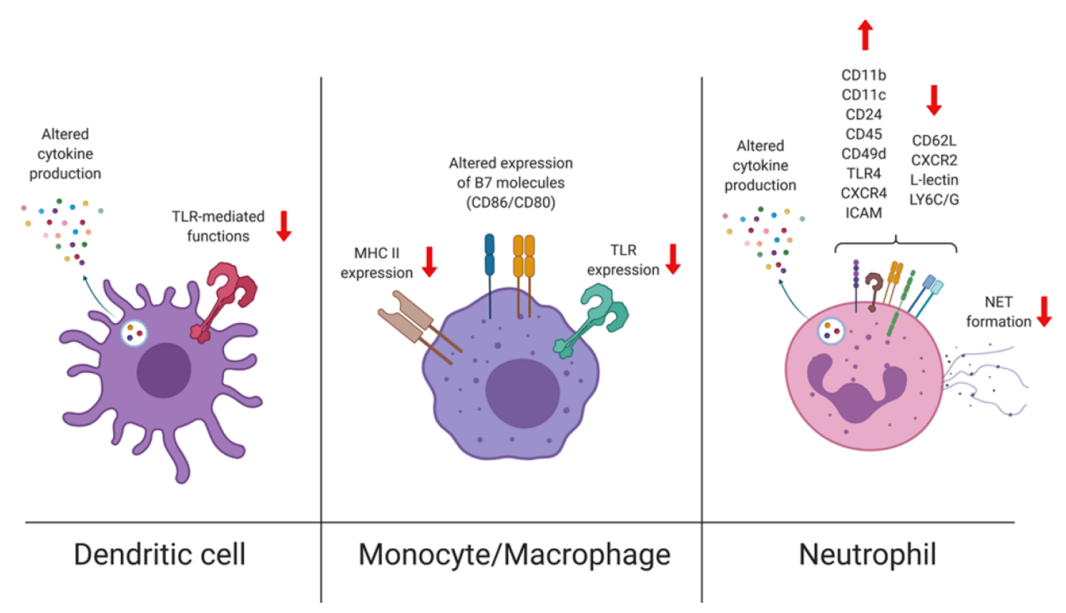

\section{Adaptive immune system}

B cell

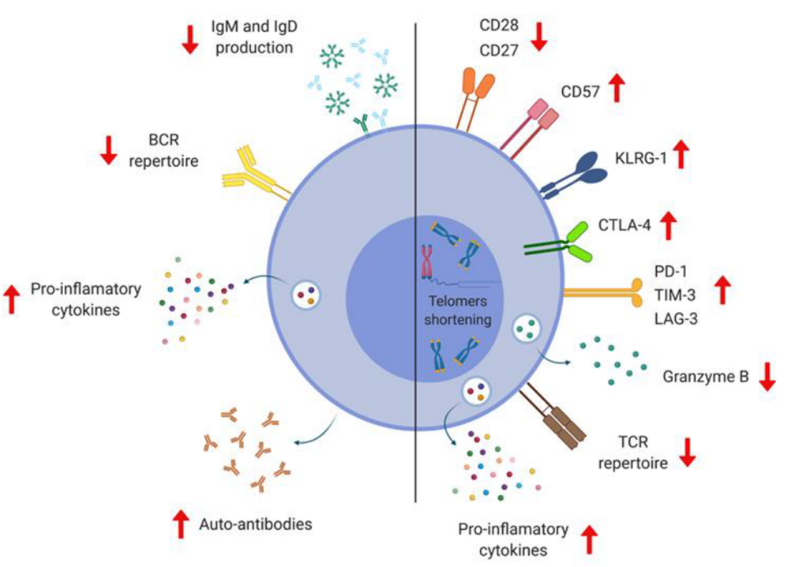

T cell

FIGURE 1 | Simplified representation of the phenotypical and functional changes affecting cells of the innate and adaptive compartment during aging. TLR, toll like receptor; MHC, major histocompatibility complex; CXCR, C-X-C chemokine receptor; ICAM, intercellular adhesion molecule; LY6C/G, Iymphocyte antigen 6 complex (locus C/G); NET, neutrophil extracellular trap; BCR, B cell receptor; TCR, T cell receptor; KLRG-1, killer-cell lectin like receptor G1; CTLA-4, cytotoxic T-lymphocyte antigen 4; PD-1, programmed cell death protein 1; TIM-3, T cell immunoglobulin and mucin domain-containing protein 3; LAG-3, lymphocyte-activation gene 3. The figure was created with BioRender.com.

activating adhesion, chemotaxis, phagocytosis as well as release of oxidants, proteases and other molecules (155-158). However, an excessive accumulation of neutrophils and hyperresponsiveness can be detrimental and cause tissue injury, as recently documented in subjects with lethal COVID-19 (159, 160). Although no difference has been found in the number of neutrophils between young and older adults, aged neutrophils exhibit a dysfunctional phagocytic and chemotactic capacity (28, $161,162)$. In aged mice, these dysfunctional cells expand and accumulate in lymph nodes due to impaired apoptosis (163, 164). Phenotypically, up-regulation of CD45, TLR4, CD24, CXCR4, CD11b, CD11c, CD49d, ICAM and down-regulation of CXCR2, CD62L, L-lectin, LY6C/G have been documented in aged human neutrophils $(156,165)$. In addition, altered 
cytokines secretion profiles, generation of reactive oxygen species (ROS) and associated microbial killing have been reported, although these findings might largely be stimulus-dependent $(28,166,167)$. Age dependent impaired formation of neutrophil extracellular traps (NETs), structures able to capture and immobilize pathogens, may explain why older adults are more susceptible to invasive bacterial infections $(29,168,169)$.

Natural killer (NK) cells are cytotoxic innate cells that eliminate infected, transformed and senescent cells (170-175). In addition, they also exert immunoregulatory activities by secreting cytokines and chemokines, which can activate and modulate the adaptive immune responses (176-178). Like other cells, NK cells are subject to age-related changes in, for instance, number, function, phenotype and redistribution $(179,180)$. As an example, there is an increased number of highly differentiated mature CD56 ${ }^{\mathrm{dim}}$ cells accompanied with a decline of immature CD56 ${ }^{\text {bright }}$ subset as well as reduced NK cell activity, which may lead to impaired immune regulation (181-184).

\section{Adaptive Immune System}

Profound age-related changes in the immune system are observed in cells of adaptive immunity. In this section, we will describe major alterations affecting aged $\mathrm{T}$ and $\mathrm{B}$ lymphocytes.

\section{T Lymphocytes}

$\mathrm{T}$ cells recognize antigens derived from pathogens or tumors via their $\mathrm{T}$ cell receptor and develop antigen-specific memory responses or tolerance (185). Upon activation, naive $\mathrm{T}$ cells proliferate, differentiate and generate effector $\mathrm{T}$ cells that can help to kill infected cells and/or to activate other cells (e.g., macrophages), and B cells. T cell precursors are generated within the bone marrow whereas their maturation and selection take place in the thymus. The thymus undergoes an involution process starting after puberty that gradually induces its atrophy $(186,187)$. Epithelial cell structure and cell turnover are altered and there is a shift toward adipose tissue that results into a reduced thymopoiesis, as well as altered transcription factors and cytokine production $(40,188)$. As a consequence, the output of newly generated naive T cells $\left(\mathrm{CCR} 7^{+}\right.$, $\mathrm{CD}_{2} \mathrm{~L}^{+}, \mathrm{CD} 4 \mathrm{RO}-, \mathrm{CD}^{-} 5 \mathrm{RA}^{+}, \mathrm{CD} 27^{+}, \mathrm{CD}^{+} 8^{+}$), and therefore the possibility to respond to novel pathogens, is impaired $(38,189,190)$. Despite the compensatory mechanism that promotes homeostatic proliferation of existing naive cells, their frequency is reduced in the periphery and in lymphoid organs (38, 42, 191-195). Coinciding with the loss of naive $\mathrm{T}$ cells, highly differentiated effector/memory $\mathrm{T}$ cells accumulate during aging, especially $\mathrm{CD} 8^{+} \mathrm{T}$ cells, many of which are dysfunctional. In particular, altered cytokine production profiles, reduced TCR clonal diversity and more self-reactive T cells have been observed (196-200) together with a general decline of the proliferative capacity in response to TCR stimulation, with $\mathrm{CD} 4^{+}$ memory T cells more prone to this loss of function $(201,202)$. An increased frequency of a subset of memory $\mathrm{CD}^{+} \mathrm{T}$ cells with a naive phenotype (TMNP) that secretes effector molecules (e.g., IFN$\gamma$, Granzyme B) in response to chronic viral stimulation has been associated with aging. The frequency of these cells positively correlates with the severity of West Nile and influenza virus infections (203). Furthermore, regulatory T cells (Tregs) with upregulated check point molecules, such as cytotoxic $\mathrm{T}$ lymphocyte antigen 4 (CTLA-4), are more abundant in older adults than in young individuals and that may affect the crosstalk between $\mathrm{T}$ cells and DCs, since Tregs can prevent the maturation of DCs $(9,204-$ 206). Age-dependent changes in T cells have, directly or indirectly, an effect on their effector functions (201). For example, the frequency of $\mathrm{CD}^{+} \mathrm{T}$ cells expressing perforin and granzyme $\mathrm{B}$ is reduced in older individuals, which correlated with an increased risk of severe influenza (207-209). Aged T cells can be phenotypically identified based on the expression of surface markers and intracellular molecules (e.g., transcription factors and cytokines). The co-stimulatory molecule CD28 is decreased and subsets of $\mathrm{CD} 4^{+} \mathrm{CD} 28^{-}$and $\mathrm{CD} 8^{+} \mathrm{CD} 28^{-} \mathrm{T}$ cells emerge in older adults (46, 210). Chronic activation of $\mathrm{T}$ cells also induces downregulation of CD28 expression and that has been associated with impaired vaccine responses $(207,211-214)$. Loss of CD27, upregulation of CD57 and KLRG-1, reduced expression of granzyme B together with telomere shortening and expression of a senescence-associated secretory phenotype (SASP), are the major hallmarks of senescent T cells $(43,46,51,211,215-218)$. The immunosenescent $\mathrm{T}$ cells with a SASP phenotype play an autocrine role and promote the recruitment of pro-inflammatory innate cells that, due to aging, are not very efficient at eliminating the senescent cells. These concomitant phenomena also contribute to the establishment of inflammaging.

Dysfunction of $\mathrm{T}$ cells caused by $\mathrm{T}$ cell exhaustion has been reported in various chronic viral infections and cancers [reviewed in (219)] $(75,220-223)$. Chronic antigenic stimulation induces upregulation of inhibitory receptors such as programmed cell death 1 (PD-1), cytotoxic T lymphocyte antigen 4 (CTLA-4), T cell immunoglobulin and mucin domain-containing protein 3 (TIM-3), and lymphocyte activation gene 3 (LAG-3), that impair TCR signaling pathways and therefore immune $\mathrm{T}$ cell functions (e.g., proliferation, transcriptional signature). SAT-B1, a chromatin organizer, is downregulated in aged $\mathrm{T}$ cells and its expression negatively correlated with PD-1 expression in virusspecific $\mathrm{CD}^{+} \mathrm{T}$ cells (224).

Although exhaustion and senescence are two distinct phenomena that differ phenotypically and functionally, both contribute to the decline of $\mathrm{T}$ cell functionality during aging. Therefore, both of these processes should be considered when developing potential novel strategies to overcome dysfunctional immune responses in this age group (225).

\section{B Lymphocytes}

$\mathrm{B}$ cells undergo profound changes during aging leading to a reduced protective vaccine efficacy and reduced control of infections. They are responsible for antibody production and have effector as well as regulatory functions. Although total B cell counts remain relatively stable in the adult population, a reduced output of naive $B$ cells from the bone marrow (BM) has been reported in mouse and human studies (226-229). Decreased production of IL-7 by stromal cells in the BM, reduces the size of the $\mathrm{B}$ cell progenitor population and affects B lymphopoiesis (230232). The function of hematopoietic stem cells (HSCs) declines with age and shifts toward the generation of non-lymphoid cells, therefore reducing the source of $B$ cell progenitors. Recently, a population of old age-associated B cells (ABC) has been identified 
in mice (233-237). These cells produce pro-inflammatory cytokines, in particular TNF- $\alpha$, that affect the generation of mature B cells (233). In humans, accumulation of B cells with similar characteristics has been described in the peripheral blood of older individuals $(238,239)$. The reduced generation of naive B cells together with a progressive accumulation of dysfunctional memory B cells in the periphery, contributes to a contraction of the $\mathrm{B}$ cell repertoire diversity that limits the ability to recognize and respond to novel antigens.

Alterations of the immunoglobulin (Ig) class-switch recombination (CSR) and somatic hypermutation (SHM), may negatively affect the generation of high-affinity antibodies and germinal center formation, both of which are very important mechanisms for the induction of protective and long-lasting immune responses. Age-related reduction and instability of the transcription factor E47 affects the enzyme activation-induced cytidine deaminase (AID) that is involved in the regulation of CSR and SHM $(62,240)$. Downregulation of AID and E47, caused by the pro-inflammatory microRNAs (miR-155 and miR-16), has been observed in B cells from aging individuals (241). Reduction in size and output of the germinal centers, as a consequence of a sub-optimal T cell help to B cells, have been reported upon infection and vaccination $(79,133,242-244)$. As demonstrated in older adults and aged mice, inflammation also leads to a decrease of chemokine CXCL12 production, which may impair the recruitment and accumulation of plasma cells in the bone marrow, the major site for antibody production (245, 246). The altered architecture of the spleen in older age negatively influences the humoral responses. For example, marginal zone of old mouse spleens showed a dysfunctional antigen recognition and migration of $B$ cells due to an impaired functionality of splenic stromal cells (247). Decrease of IgM and IgD serum levels, probably due to the shift to a more differentiated and effector $B$ cell population has been observed in humans (248-250). Finally, it has been reported that senescent B cells can produce auto-antibodies, which may lead to the development of autoimmune diseases (229, 251-253).

\section{ROLE OF VIRAL INFECTIONS IN OLDER ADULTS}

Immunosenescence accounts for an increased susceptibility to viral infections such as those caused by influenza viruses and RSV and reduced vaccine efficacy in this age group. In addition, chronic stimulation of the immune system operated by viruses establishing latent infections, that can re-activate from time to time, may further impair the overall immune status in older individuals.

\section{Human Cytomegalovirus}

Human cytomegalovirus (HCMV) is a $\beta$-herpes virus that causes lifelong latent infections in a large proportion of the human population. The mechanisms involved in HCMV latency are still poorly understood and despite extensive literature on how HCMV infection influences the adaptive immune response in older adults, this is still a matter of debate (254). Immunologically, HCMV infection is characterized by inflation of HCMV-specific memory T cells, mostly $\mathrm{CD}^{+}$, with proliferation of oligoclonal T cells (96, 255-262). The accumulation of these terminally differentiated apoptosis-resistant CMV-specific $\mathrm{T}$ cells clones is believed to compromise the overall $\mathrm{T}$ cell repertoire diversity. Chronic HCMV infection also triggers an increased secretion of proinflammatory cytokines that favors cell damage and contributing to inflammaging, although its impact in older adults is still unclear (263-266). CMV-seropositivity has been associated with reduced immune response to (influenza) vaccination in older adults, but also in younger subjects $(267,268)$. Increased cardiovascular problems and mortality rate have been also reported in $\mathrm{CMV}^{+}$ older individuals. However, data are often inconclusive and associations are still controversial, not confirmed and do not need to have a causal relationship (267, 269-274). In contrast, CMV positivity may exert a beneficial effect by improving $\mathrm{CD}^{+} \mathrm{T}$ cell polyfunctionality, as demonstrated in healthy young individuals $(263,275,276)$. Thus, chronic HCMV infections may have an impact on immune responses induced in older people after infection or vaccination. More studies are warranted to further investigate this association, which may guide the development of effective therapeutic strategies.

\section{Varicella Zoster Virus}

Varicella zoster virus (VZV) belongs to the $\alpha$-herpesvirus family (277). This virus is highly infectious (about 90\% of adults are infected) and produces "varicella", also known as "chickenpox", a self-limiting disease which is commonly experienced during childhood and is characterized by widespread vesicular rash and fever, that usually resolves in 1-2 weeks (278-280). Despite a robust primary response, VZV is not eliminated from the body and can remain in the spinal and cranial sensory ganglia in a lifelong latent state $(84,281)$. The mechanisms leading to latency and subsequent reactivation are still to be unraveled. However, a recent study has suggested VLT-ORF63 transcripts from VZV as potential inducers of reactivation (282). In addition, cellmediated immunity appears to play an important role in the immune response to VZV and also latency (283-285). Reactivation occurs in $10-20 \%$ of seropositive individuals and causes the so-called "herpes zoster" (HZ) or "shingles", a painful rash that mainly affects older adults and immunocompromised individuals, in which VZV-specific immune control has declined below a critical level (286). Even if VZV primary infection could lead to complications (e.g., bacterial infections, encephalitis, hemorrhage and pneumonia), a later reactivation process may trigger severe neurological complications, including post-herpetic neuralgia (PHN) (84, 286-289). PHN can last for years, or become permanent, with age being the most important risk factor correlating with its development. Importantly, the severity of $\mathrm{HZ}$ has been associated with a reduced frequency of VZVspecific effector memory $\mathrm{T}$ cells, highlighting the crucial role of cell-mediated immunity (290).

Three vaccines are currently licensed for preventing VZV associated disease. The most widely used VZV vaccine is a live attenuated vaccine based on the OKA-strain that can be administered in one- or two-dose regimens during childhood $(286,291-293)$. Although this vaccine is very effective (up to $98 \%$ ) 
in protecting from severe VZV infection, it does not prevent latency and reactivation of the virus. Moreover, it is not suitable for immunocompromised individuals, due to a less favorable safety profile (294).

Two vaccines, Zostavax ${ }^{\mathrm{TM}}$ and Shingrix ${ }^{\mathrm{TM}}$, have been developed to prevent $\mathrm{HZ}$ (shingles). Zostavax ${ }^{\mathrm{TM}}$ is a live attenuated vaccine licensed in 2006 for individuals $>50$ years of age and contains 14fold more of the OKA-strain than needed to prevent varicella. Several studies have indicated that the efficacy afforded by this vaccine wanes with age and appears to be inferior to that obtained with Shingrix $^{\mathrm{TM}}(295-297)$. For this reason, the Zostavax ${ }^{\mathrm{TM}}$ is, effective July 2020, no longer available for use in the US. A new Zostavax ${ }^{\mathrm{TM}}$-based vaccine inactivated by gamma irradiation is under clinical investigation. Data obtained during the phase III clinical trial indicated that the vaccine is well tolerated with no significant safety issues. However, the immune response is not as strong as those induced with other vaccines and it should also be administered in a four-dose regimen (298-300).

Shingrix ${ }^{\mathrm{TM}}$ is a recombinant adjuvanted vaccine licensed in 2017 for people $>50$ years of age. The vaccine contains the recombinant glycoprotein $\mathrm{E}(\mathrm{gE})$ formulated with the AS01B adjuvant system. The $\mathrm{gE}$ is involved in viral replication, cell to cell virus transfer and is highly expressed in VZV infected cells, being also the primary target of the $\mathrm{T}$ cell response $(279,301-$ 303). This vaccine is able to generate strong humoral and cellmediated immunity, therefore overcoming the decline of the VZV-specific response observed in older individuals. The efficacy of this vaccine for preventing $\mathrm{HZ}$ and possible complications, such as PHN, is high irrespective of age and, importantly, the vaccine-induced immunity is long lasting and can persist up to 9 years $(25,304-306)$. When compared to the live-attenuated vaccine, Shingrix ${ }^{\mathrm{TM}}$ induced higher frequency of gE-specific $\mathrm{CD} 4^{+}$and $\mathrm{CD} 8^{+}$ memory $\mathrm{T}$ cells in older adults (307). VZV-specific $\mathrm{CD}^{+} \mathrm{T}$ cells have been associated with a positive vaccine outcome (308). Shingrix $^{\mathrm{TM}}$, unlike Zostavax ${ }^{\mathrm{TM}}$, has shown a favorable safety profile in immunocompromised and transplant recipients (25, $305,306,309,310)$. However, Shingrix ${ }^{\mathrm{TM}}$ reactogenicity, due to the adjuvant, appeared to be higher compared to other vaccines used for older individuals, although serious adverse events and immune-mediated diseases were not increased in the vaccinees. The success of this vaccine for older adults may reside in the use of an adjuvant that provides a proper activation of the innate immune system, which is pivotal for the induction of an effective and longlasting adaptive immune response.

\section{SARS CoV-2}

Since the first reported case of COVID-19 in December 2019, the severe acute respiratory syndrome coronavirus 2 (SARS CoV-2) has infected more than 130 million people and caused over 3 million deaths worldwide (https://covid19.who.int/). SARS CoV2 is a positive sense single stranded RNA virus that uses its $S$ protein to bind and infect respiratory epithelial cells that express its receptor angiotensin converting enzyme 2 (ACE-2), including type II pneumocytes in the lung (311). Although the majority of infected people only develop mild disease, some develop severe disease often with a fatal outcome. Especially older people have been affected disproportionally with high case fatality rates.
In the US, for example, $80 \%$ of all fatal cases were older than 65 years of age (CDC - https://www.cdc.gov/coronavirus/2019ncov/need-extra-precautions/older-adults.html). Furthermore, the more severe course of infection observed in older people often requires hospitalization and treatment in intensive care units (312-314). Studies to elucidate the molecular and cellular mechanisms responsible for the worse outcome of SARS CoV-2 infection in aged people are ongoing. However, the strong association between age and severity of infection seems to be a common feature to other coronavirus infections (e.g., SARS CoV1 and MERS) and it has also been observed for other respiratory viral pathogens, such as influenza viruses (315-318). Underlying co-morbidities associated with aging (e.g., cancer, hypertension, cardiovascular diseases diabetes or autoimmunity), genetic factors and reduced ability to mount adequate adaptive immune responses due to presence of dysfunctional aged immune cells, may account for the severe clinical outcome $(319,320)$. Preexisting SARS CoV-2 cross-reactive $\mathrm{T}$ cells induced by previous exposures to seasonal human common cold coronavirus are readily detected in younger individuals, but are virtually absent in older people, suggesting that this age group may not benefit from a potential protective effect of these pre-existing crossreactive $\mathrm{T}$ cells (19). A chronic, low-grade inflammation (inflammaging), the main hallmark of aging, has been suggested to play a critical role in promoting "cytokine storm" and consequent acute respiratory distress syndrome (ARDS), often observed in older individuals (321-325). The downregulation of the ACE-2 receptor together with a dysregulated angiotensin-II pathways (renin-angiotensin-aldosterone system) may foster the uncontrolled and exaggerated inflammatory response leading to pulmonary damages, multi-organ dysfunction and ultimately, death $(326,327)$.

The ongoing COVID-19 vaccination campaign in older subjects has already been shown very successful and significantly reduced hospitalizations and mortality among people of this age group. It also demonstrates that despite high age and associated immunosenescence, successful vaccination is still possible in this age group.

\section{Influenza Virus}

Seasonal influenza viruses are among the leading causes of respiratory infections and responsible for 290,000-650,000 deaths annually worldwide (100). Despite the high vaccine coverage among individuals $>65$ years of age in some countries, this age group accounts for the vast majority of deaths and hospitalizations (CDC - https://www.cdc.gov/flu/index.htm). Although the mechanisms underlying increased severity of influenza virus infection in older individuals are still not fully understood, comorbidities such chronic and metabolic diseases, obesity, immunosuppression, and frailty represent a risk for disease severity and development of complications (328-330).

Age-related immunosenescence affects the functionality of $\mathrm{B}$ and T cells, hindering an optimal protective response upon seasonal influenza vaccination. Current influenza vaccines mainly provide protection through the induction of antibodies that antigenically match the epidemic strains $(331,332)$. Several studies have indicated that influenza-specific antibodies in older adults decline 
faster, failing to maintain long-lasting protective levels (333-336). Moreover, these individuals exhibit a reduced accumulation of " $d e$ novo" mutations in the Ig variable gene affecting the adaptability of their antibody responses to influenza virus $(337,338)$. Therefore, this age group mainly rely on cross-reactive memory B cells generated early in life (339). Interestingly, a recent study has shown that influenza virus infection predominantly recalls preexisting memory B cells against non-neutralizing epitopes in contrast to vaccination that mainly targets memory B cells to protective HA epitopes. One could speculate that boosting preexisting immunity may play a key role in susceptibility versus protection upon influenza virus infection $(339,340)$. Additional defects influencing the B cell responses to influenza virus infection or vaccination are reviewed elsewhere (99).

T cells, especially $\mathrm{CD}^{+}$, are an important correlate of protection against influenza virus infections also providing heterosubtypic immunity (341-344). In older adults, phenotypic and functional defects in the virus-specific $\mathrm{CD}^{+}$responses upon influenza virus infection have been demonstrated $(214,345,346)$. In older adults the number of IL-7R $\alpha^{\text {low }}$ effector memory $\mathrm{CD}^{+} \mathrm{T}$ cells, a subset accumulating during aging, correlated with the vaccine-induced immune response determined by antibody production. This suggests a possible implication of the IL-7Ro ${ }^{\text {low }}$ effector memory $\mathrm{CD}^{+} \mathrm{T}$ cell population in the aging related alterations (346).

Several studies have indicated that the functionality of the $\mathrm{CD}^{+} \mathrm{T}$ cells becomes compromised, including $\mathrm{T}$ follicular helper cells, which are essential for an optimal B cell response. Consequently, these functional defects impair the humoral response induced by vaccination and the formation of $\mathrm{B}$ cell memory (347-349). It was shown that repeated vaccinations may lead to a reduced $\mathrm{CD} 4^{+} \mathrm{T}$ cell response, which correlates with a reduced antibody response (350).

Strategies to increase vaccine efficacy in older adults have been developed and include the use of a high dose antigen or adjuvant and alternative administration routes and will be discussed in the next section. These improved vaccines boost not only the humoral but also cell-mediated immune responses, in contrast to the standard vaccine (351). However, the mechanisms underlying the success or failure of a vaccination strategy is still not completely understood. It will also be important to gain more insights into new correlates of protection, other than virus neutralizing antibodies, that may be more suitable for predicting influenza vaccine outcome in older adults and would guide the design of new generation influenza vaccines (208).

\section{Respiratory Syncytial Virus}

Respiratory syncytial virus (RSV) belongs to the family of Pneumoviridae and is the leading cause of lower respiratory tract infection in infants and young children. RSV was not recognized as a potential problem in the adult population until outbreaks occurred in long-term care nursing facilities $(352,353)$. RSV causes significant burden of severe disease in older adults with $2-5 \%$ mortality rate (354). A relatively short-lived immunity after natural infection together with suboptimal/dysfunctional response of the "aged" immune system might be at the basis of the poor outcome of infections later in life. Despite the large number of candidate antivirals and vaccines against RSV in the pipeline, only a single antiviral treatment is approved, albeit with limited effectiveness and no vaccine has been licensed yet $(355,356)$. The correlates of immunological protection remain poorly understood which represents a major obstacle in RSV vaccine development, but antibodies to the $\mathrm{F}$ and $\mathrm{G}$ envelope proteins contribute to protective immunity (357-360). Both systemic and mucosal humoral immunity have been associated with protection (361-363). The frequency of RSV-specific CD4 ${ }^{+}$and $\mathrm{CD}^{+} \mathrm{T}$ cells is reduced in older adults compared to that in young adults (364-366). Furthermore, severity of the disease has been shown to correlate with reduced RSV neutralizing antibody titers and low numbers of $\mathrm{CD}^{+}$memory T cells $(367,368)$.

\section{THERAPEUTIC APPROACHES TO INCREASE IMMUNITY IN OLDER ADULTS}

The immune system is subject to several changes throughout life, and protects against infectious pathogens, but ultimately lose functionality by e.g., immunosenescence. Immunosenescence is partly influenced by external factors such as diet and infections, but also has a genetic component (369-375). Centenarians, for instance, seem to have gene variants that allow an optimized balance between pro- and anti-inflammatory molecules (376). The genetic study of this variation could reveal information about the immunosenescence process and how it is triggered, opening a window of opportunity for potential new therapeutic treatments (53). In addition, a personalized genetic analysis could help identify which treatment will be more effective at overcoming immunosenescence on an individual basis. These aging-related hallmarks are independent phenomena but causally connected.

Several studies have provided important insights into the biological mechanisms underlying the causes of immunosenescence and have identified possible therapeutic targets (Figure 2) (377-379).

\section{Senolytic Drugs}

Senescent cells are induced by cellular stress, which can occur at any age. Therefore, they can be found at any stage of life and play a beneficial role in embryogenesis, tissue repair/remodeling and tumor suppression in adulthood (380-382). Yet, secretion of soluble mediators, such as chemokines, favors the removal of senescent cells by other immune cells (e.g., macrophages and NKs) $(383,384)$. This process becomes less efficient with aging and results in accumulation of senescent, apoptosis-resistant cells that, together with a pro-inflammatory phenotype, contribute to tissue dysfunction and pathological manifestations (385). Chemotherapy/radiotherapy, atherosclerosis, organ transplantations or smoking, are factors among others, that accelerate immunosenescence, mainly by inducing DNA and telomere damage (386-389). In this regard, stimulation of cell death by using pharmacologically active small molecules, also known as senolytic drugs, has been identified as a promising anti-aging treatment (390). Some of these drugs inhibit the pro-survival pathways, involving the BCL-2 family members, p53 and PI3K/AKT pathways, leading to selective apoptosis of senescent cells $(225,391,392)$. Dasatinib, a kinase inhibitor, and quercetin, a flavonoid targeting the PI3K/AKT, have been proven effective in 
eliminating senescent cells both in vivo and in vitro (393). Fisetin, another natural molecule, also appears to have senolytic properties (394). In addition, inhibitors of the chaperon HSP90, downregulate the anti-apoptotic PI3K/AKT pathway whereas a peptide altering the interaction between the transcription factor FOXO and p53, induces apoptosis of senescent cells (391, 395-398).

\section{NF-кB Regulators}

The SASP is heterogeneous, depending on the senescent cell type or mechanism that have induced senescence. Yet, some SASPassociated cytokines and growth factors are commonly secreted by different senescent cells (e.g., IL-6, IL-8, TGF- $\beta$ or activin A) (71, 399-402). Interestingly, the SASP has also been shown to include secretion of extracellular vesicles, which seem to be involved in intercellular communication and inflammatory exacerbation (403405). In this regard, another promising therapeutic approach for targeting cellular senescence is the modulation of the NF- $\kappa \mathrm{B}$ regulators, such as p53 and p38 MAPK pathways and mTOR (mammalian target of rapamycin), that can mitigate the detrimental effect of the SASP by dampening the production of pro-inflammatory cytokines (e.g., IL-1, IL-6 and IL-8) (406-408). For example, the p38 MAPK pathway has been suggested to boost immunosenescence by positively regulating IFN- $\gamma$ production in $\mathrm{T}$ cells and by altering autophagy, which causes an increase of dysfunctional cells $(409,410)$. First and second generation p38 inhibitors suppress SASP expression in senescent cells $(411,412)$. Inhibition of the sestrin-dependent MAPK activation complex has been shown to improve $\mathrm{T}$ cell activity in older adults, which could be associated with an increased vaccine efficacy (413). Caloric restriction can also dampen the production of pro-inflammatory cytokines by regulating the MAPK and NF- $\mathrm{KB}$ pathways $(414,415)$. Inhibitors targeting the mTOR complex, such as the immunosuppressant drug Rapamycin and its analogues, are effective in improving the outcome of several diseases affecting older individuals (e.g., respiratory viral infections), as wells as vaccination (e.g., influenza vaccine) $(407,416)$. These drugs reduce the SASP while improving the innate immune response. For instance, both Rapamycin and a second-generation mTOR inhibitor RTB101, are currently under clinical investigation as possible COVID-19 treatment for adults aged $>60$ years of age (NCT04584710 and NCT04409327). Metformin, a widely used treatment for type II diabetes, also has been evaluated for its inhibitory effect on the SASP and as immunomodulatory agent (417). Although these drugs might offer the unique opportunity to dampen detrimental effects of aging on the immune cells or induce apoptosis of the senescent cells, it should be pointed out that their safety profile is often a matter of concern.

\section{Improved Vaccines}

Vaccination is the most effective measure to prevent infections and reduce the disease severity but unfortunately, their effectiveness appears to be lower in older adults.

The use of adjuvants as component of improved vaccines for use in older people has proven to be another strategy to partially overcome immunosenescence by increasing immunogenicity and durability of vaccine induced immune responses. A licensed
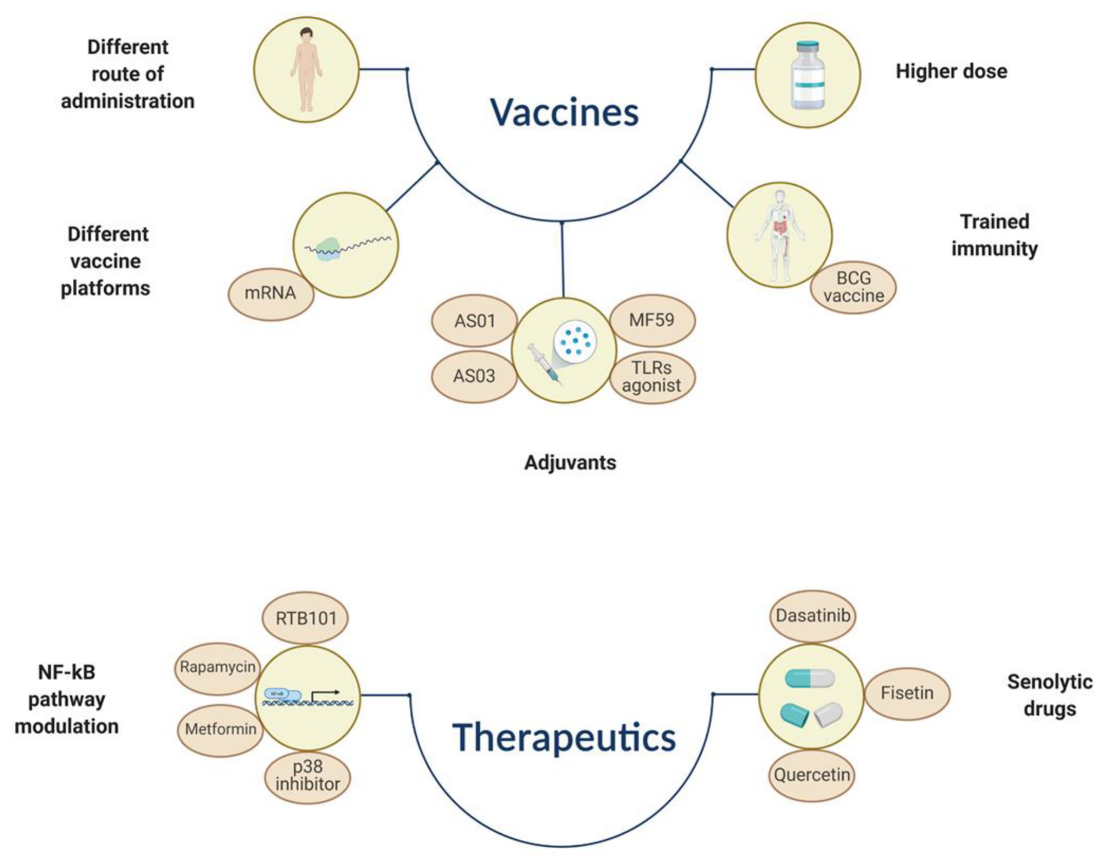

FIGURE 2 | Simplified representation of different approaches that aim to overcome immunosenescence by increasing vaccine immunogenicity/efficacy or by using therapeutics that can dampen the SASP effect or induce selective apoptosis of immunosenescent cells. BCG, Bacillus Calmette-Guérin; TLR, toll like receptor. The figure was created with BioRender.com. 
influenza vaccine containing MF5 $9^{\circledR}$, an oil-in-water emulsion, elicited higher antibody response in older individuals compared to the standard influenza vaccine and, interestingly, a broader antibody response also directed toward heterologous vaccine strains (103, $418,419)$. Although the mode of action is not completely understood, MF5 $9^{\circledR}$ is believed to activate innate immune cells and favor the germinal center reaction (420, 421). Another emulsion-based adjuvant, AS03, has been licensed and used during the $2009 \mathrm{H} 1 \mathrm{~N} 1$ influenza pandemic (422). The adjuvant system AS01, component of the herpes zoster vaccine, induces antibody and cytotoxic $\mathrm{CD} 8{ }^{+} \mathrm{T}$ cell responses and also activates innate immune cells $(423,424)$. Several other adjuvants, including Toll-like receptors agonists, are currently in the pre-clinical phase or undergoing clinical testing and have been reviewed elsewhere (425). Additional strategies, including the use of higher dose of vaccine antigen or alternative routes of vaccine administration (e.g., intradermal instead of intramuscular), have been successfully developed for influenza vaccines targeting the older population $(426,427)$. The improved humoral and cell-mediated immune response achieved with such vaccines has been recently confirmed by a meta-analyses conducted on 39 clinical trials, and in a head-to-head comparison clinical trial $(351,428)$. Promising data have been reported in subjects of $>60$ years of age receiving a candidate vaccine containing a recombinant $\mathrm{HA}$ nanoparticle produced in insect cells and formulated with a saponin-based Matrix-M adjuvant. This vaccine was well-tolerated and induced a potent immune responses when compared to the standard highdose inactivated influenza vaccine (429).

A messenger RNA (mRNA) vaccine against SARS-CoV-2 has been recently licensed and, interestingly, the immune responses induced by this vaccine in older adults, who are most at risk for developing severe disease, was similar to that obtained in younger people with over $90 \%$ protective efficacy in adults of $>65$ years old. Several factors may account for the excellent efficacy including an adequate involvement and stimulation of the innate immune system and increased vaccine uptake due to its formulation (430). More studies are warranted to unravel the immunological mechanisms governing this outstanding protective efficacy. These findings may be important for the future use of this vaccine platform to protect old individuals from other viral and maybe also bacterial pathogens.

The data obtained with the "improved" and also with the mRNA vaccines suggest that reduced vaccine efficacy might be just a limitation of currently used vaccination strategies and that intrinsic features of aging can be overcome with better vaccines. A more detailed understanding of changes affecting the immune system over time will provide fundamental insights into the biology of immunosenescence and would greatly facilitate the rational design of tailor-made vaccines for older adults. Moreover, the presence of chronic diseases and frailty, defined as a decline of function across multiple organ systems, may be better predictors of poor vaccine immunogenicity than age alone (431).

"Trained immunity" or "innate immune memory" is a recent and interesting concept that defines the ability of innate cells to form immune memory and therefore displaying characteristics of adaptive immunity $(64,432,433)$. Epigenetic and metabolic mechanisms are thought to be responsible for this phenomenon. An increasing number of studies have shown that several vaccines such as those against smallpox, oral polio, measles and tuberculosis (Bacillus Calmette-Guérin, BCG), induce non-specific protective effects also against heterologous, "off-target", infectious diseases (434, 435). Interestingly, BCG vaccination reduces respiratory infections in older adults and recent data have demonstrated that the innate immune function is less affected by aging than adaptive immunity, suggesting that trained immunity may be functional in this age group $(436,437)$. Moreover, BCG vaccination has been shown to increase the immunogenicity of subsequent influenza vaccination, highlighting its adjuvant-like property (438). In a recent review, "trained immunity" was proposed as a new target to enhance immune responses in older adults (439). Although data are still scarce and more insights are needed, it may represent a valuable target also for designing better vaccines. However, it cannot be excluded that the excess of cytokines induced by activation of innate cells might have negative effects on the immune system of older adults.

\section{CONCLUSIONS}

The ongoing COVID-19 pandemic and its tremendous impact on older individuals highlights the need for the development of therapeutic and preventive measures to protect this vulnerable age group. Therefore, it is of utmost importance to advance our understanding of the mechanisms (molecular, cellular, genetic, environmental, etc.) responsible for aging and the development of immunosenescence, which will aid developing novel medical interventions. Intrinsic and extrinsic cell stress factors induce cellular senescence, which is mainly characterized by cell cycle arrest $\left(\mathrm{G}_{0} / \mathrm{G}_{1}\right)$ and secretion of soluble factors (SASP) in the extracellular environment (440). Despite recent technological advances, phenotypical characterization of senescent cells is still challenging due to a lack of defined and univocal/universal biomarkers but also for their heterogeneous nature and dynamic evolution. It is still not clear how many different subsets of senescent cells can be identified and their distribution in tissues and periphery. Although some interesting animal models to study cellular senescence have been developed, their results might not be easily translated to the human situation $(441,442)$. To obtain a better insight into the complexity of immune ageing/immunosenescence and thus the possibility to decipher and dissect mechanisms and cells involved, requires the use of multiple scientific approaches and disciplines (e.g., high-resolution omicstechnologies, multiparametric analyses, system biology and big data analyses). With the information obtained, better prophylactic and therapeutic interventions can be developed to prevent deterioration of the health status, often associated with aging and immunosenescence. This way, the quality of life in this age group can be maintained and mortality, including that caused by infectious agents, reduced.

\section{AUTHOR CONTRIBUTIONS}

MP-P, AO, TB, HE, GR, and GS conceptualized and composed the manuscript. GR and GS supervised all aspects of the manuscript preparation. All authors contributed to the article and approved the submitted version. 


\section{FUNDING}

This work was supported by the Alexander von Humboldt Foundation in the framework of the Alexander von Humboldt Professorship endowed by the German Federal Ministry of

\section{REFERENCES}

1. Walford RL. Immunologic Aspects of Aging. Klin Wochenschr (1969) 47 (11):599-605. doi: 10.1007/BF01876949

2. Hainz U, Jenewein B, Asch E, Pfeiffer KP, Berger P, Grubeck-Loebenstein B. Insufficient Protection for Healthy Elderly Adults by Tetanus and TBE Vaccines. Vaccine (2005) 23(25):3232-5. doi: 10.1016/j.vaccine.2005.01.085

3. Song JY, Cheong HJ, Hwang IS, Choi WS, Jo YM, Park DW, et al. LongTerm Immunogenicity of Influenza Vaccine Among the Elderly: Risk Factors for Poor Immune Response and Persistence. Vaccine (2010) 28 (23):3929-35. doi: 10.1016/j.vaccine.2010.03.067

4. Tohme RA, Awosika-Olumo D, Nielsen C, Khuwaja S, Scott J, Xing J, et al. Evaluation of Hepatitis B Vaccine Immunogenicity Among Older Adults During an Outbreak Response in Assisted Living Facilities. Vaccine (2011) 29(50):9316-20. doi: 10.1016/j.vaccine.2011.10.011

5. Van Der Meeren O, Crasta P, Cheuvart B, De Ridder M. Characterization of an Age-Response Relationship to GSK's Recombinant Hepatitis B Vaccine in Healthy Adults: An Integrated Analysis. Hum Vaccin Immunother (2015) 11(7):1726-9. doi: 10.1080/21645515.2015.1039758

6. Yang S, Tian G, Cui Y, Ding C, Deng M, Yu C, et al. Factors Influencing Immunologic Response to Hepatitis B Vaccine in Adults. Sci Rep (2016) 6:27251. doi: 10.1038/srep27251

7. Pawelec G. Age and Immunity: What is "Immunosenescence"? Exp Gerontol (2018) 105:4-9. doi: 10.1016/j.exger.2017.10.024

8. Dodig S, Cepelak I, Pavic I. Hallmarks of Senescence and Aging. Biochem Med (Zagreb) (2019) 29(3):030501. doi: 10.11613/BM.2019.030501

9. Weinberg A, Pang L, Johnson MJ, Caldas Y, Cho A, Tovar-Salazar A, et al. The Effect of Age on the Immunogenicity of the Live Attenuated Zoster Vaccine Is Predicted by Baseline Regulatory $\mathrm{T}$ Cells and Varicella-Zoster Virus-Specific T Cell Immunity. J Virol (2019) 93(15):e00305-19. doi: 10.1128/JVI.00305-19

10. Roebuck J. When Does Old-Age Begin - Evolution of the English Definition. J Soc History (1979) 12(3):416-28. doi: 10.1353/jsh/12.3.416

11. Steens A, Eriksen HM, Blystad H. What are the Most Important Infectious Diseases Among Those $>/=65$ Years: A Comprehensive Analysis on Notifiable Diseases, Norway, 1993-2011. BMC Infect Dis (2014) 14:57. doi: 10.1186/1471-2334-14-57

12. Beard JR, Officer A, de Carvalho IA, Sadana R, Pot AM, Michel JP, et al. The World Report on Ageing and Health: A Policy Framework for Healthy Ageing. Lancet (2016) 387(10033):2145-54. doi: 10.1016/S0140-6736(15)00516-4

13. Demicheli V, Jefferson T, Di Pietrantonj C, Ferroni E, Thorning S, Thomas RE, et al. Vaccines for Preventing Influenza in the Elderly. Cochrane Database Syst Rev (2018) 2:CD004876. doi: 10.1002/14651858.CD004876.pub4

14. Akbar AN, Gilroy DW. Aging Immunity may Exacerbate COVID-19. Science (2020) 369(6501):256-7. doi: 10.1126/science.abb0762

15. Fried MW, Crawford JM, Mospan AR, Watkins SE, Munoz Hernandez B, Zink RC, et al. Patient Characteristics and Outcomes of 11,721 Patients With COVID19 Hospitalized Across the United States. Clin Infect Dis (2020) ciaa1268. doi: 10.1093/cid/ciaa1268

16. Lee JY, Kim HA, Huh K, Hyun M, Rhee JY, Jang S, et al. Risk Factors for Mortality and Respiratory Support in Elderly Patients Hospitalized With COVID-19 in Korea. J Korean Med Sci (2020) 35(23):e223. doi: 10.3346/ jkms.2020.35.e223

17. Wang W, Xu Y, Gao R, Lu R, Han K, Wu G, et al. Detection of SARS-CoV-2 in Different Types of Clinical Specimens. JAMA (2020) 323(18):1843-4. doi: 10.1001/jama.2020.3786

18. Channappanavar R, Perlman S. Age-Related Susceptibility to Coronavirus Infections: Role of Impaired and Dysregulated Host Immunity. J Clin Invest (2020) 130(12):6204-13. doi: 10.1172/JCI144115
Education and Research; the European Union's Horizon 2020 research and innovation program under grant agreement No 848166 (ISOLDA) and the German Research Foundation, Excellence Strategy program-EXC 2155 Resolving Infection Susceptibility, "RESIST".

19. Saletti G, Gerlach T, Jansen JM, Molle A, Elbahesh H, Ludlow M, et al. Older Adults Lack SARS CoV-2 Cross-Reactive T Lymphocytes Directed to Human Coronaviruses OC43 and NL63. Sci Rep (2020) 10(1):21447. doi: 10.1038/s41598-020-78506-9

20. Amsterdam D, Ostrov BE. The Impact of the Microbiome on Immunosenescence. Immunol Invest (2018) 47(8):801-11. doi: 10.1080/08820139.2018.1537570

21. Del Giudice G, Goronzy JJ, Grubeck-Loebenstein B, Lambert PH, Mrkvan T, Stoddard JJ, et al. Fighting Against a Protean Enemy: Immunosenescence, Vaccines, and Healthy Aging. NPJ Aging Mech Dis (2018) 4:1. doi: 10.1038/ s41514-017-0020-0

22. Muller L, Fulop T, Pawelec G. Immunosenescence in Vertebrates and Invertebrates. Immun Ageing (2013) 10(1):12. doi: 10.1186/1742-4933-10-12

23. Holder A, Mirczuk SM, Fowkes RC, Palmer DB, Aspinall R, Catchpole B. Perturbation of the $\mathrm{T}$ Cell Receptor Repertoire Occurs With Increasing Age in Dogs. Dev Comp Immunol (2018) 79:150-7. doi: 10.1016/j.dci.2017. 10.020

24. Mietsch M, Paque K, Drummer C, Stahl-Hennig C, Roshani B. The Aging Common Marmoset's Immune System: From Junior to Senior. Am J Primatol (2020) 82(6):e23128. doi: 10.1002/ajp.23128

25. Schwarz TF, Volpe S, Catteau G, Chlibek R, David MP, Richardus JH, et al. Persistence of Immune Response to an Adjuvanted Varicella-Zoster Virus Subunit Vaccine for Up to Year Nine in Older Adults. Hum Vaccin Immunother (2018) 14(6):1370-7. doi: 10.1080/21645515.2018.1442162

26. Arai Y, Martin-Ruiz CM, Takayama M, Abe Y, Takebayashi T, Koyasu S, et al. Inflammation, But Not Telomere Length, Predicts Successful Ageing At Extreme Old Age: A Longitudinal Study of Semi-Supercentenarians. EBioMedicine (2015) 2(10):1549-58. doi: 10.1016/j.ebiom.2015.07.029

27. Niwa Y, Kasama T, Miyachi Y, Kanoh T. Neutrophil Chemotaxis, Phagocytosis and Parameters of Reactive Oxygen Species in Human Aging: Cross-Sectional and Longitudinal Studies. Life Sci (1989) 44 (22):1655-64. doi: 10.1016/0024-3205(89)90482-7

28. Wenisch C, Patruta S, Daxbock F, Krause R, Horl W. Effect of Age on Human Neutrophil Function. J Leukoc Biol (2000) 67(1):40-5. doi: 10.1002/ jlb.67.1.40

29. Hazeldine J, Harris P, Chapple IL, Grant M, Greenwood H, Livesey A, et al. Impaired Neutrophil Extracellular Trap Formation: A Novel Defect in the Innate Immune System of Aged Individuals. Aging Cell (2014) 13(4):690-8. doi: 10.1111/acel.12222

30. Agrawal A, Agrawal S, Gupta S. Role of Dendritic Cells in Inflammation and Loss of Tolerance in the Elderly. Front Immunol (2017) 8:896. doi: 10.3389/ fimmu.2017.00896

31. Drew W, Wilson DV, Sapey E. Inflammation and Neutrophil Immunosenescence in Health and Disease: Targeted Treatments to Improve Clinical Outcomes in the Elderly. Exp Gerontol (2018) 105:70-7. doi: 10.1016/j.exger.2017.12.020

32. Sapey E, Greenwood H, Walton G, Mann E, Love A, Aaronson N, et al. Phosphoinositide 3-Kinase Inhibition Restores Neutrophil Accuracy in the Elderly: Toward Targeted Treatments for Immunosenescence. Blood (2014) 123(2):239-48. doi: 10.1182/blood-2013-08-519520

33. Ward JR, Heath PR, Catto JW, Whyte MK, Milo M, Renshaw SA. Regulation of Neutrophil Senescence by Micrornas. PLoS One (2011) 6(1):e15810. doi: 10.1371/journal.pone.0015810

34. Pepper M, Jenkins MK. Origins of CD4(+) Effector and Central Memory T Cells. Nat Immunol (2011) 12(6):467-71. doi: 10.1038/ni.2038

35. Samji T, Khanna KM. Understanding Memory CD8(+) T Cells. Immunol Lett (2017) 185:32-9. doi: 10.1016/j.imlet.2017.02.012

36. Johnson ED, Cole GA. Functional Heterogeneity of Lymphocytic Choriomeningitis Virus-Specfic T Lymphocytes. I. Identification of Effector Amd Memory Subsets. J Exp Med (1975) 141(4):866-81. doi: 10.1084/jem.141.4.866 
37. Haynes L, Eaton SM, Burns EM, Randall TD, Swain SL. Cd4 T Cell Memory Derived From Young Naive Cells Functions Well Into Old Age, But Memory Generated From Aged Naive Cells Functions Poorly. Proc Natl Acad Sci USA (2003) 100(25):15053-8. doi: 10.1073/pnas.2433717100

38. Goronzy JJ, Lee WW, Weyand CM. Aging and T-cell Diversity. Exp Gerontol (2007) 42(5):400-6. doi: 10.1016/j.exger.2006.11.016

39. Chidrawar S, Khan N, Wei W, McLarnon A, Smith N, Nayak L, et al. Cytomegalovirus-Seropositivity has a Profound Influence on the Magnitude of Major Lymphoid Subsets Within Healthy Individuals. Clin Exp Immunol (2009) 155(3):423-32. doi: 10.1111/j.1365-2249.2008.03785.x

40. Nikolich-Zugich J. Aging of the T Cell Compartment in Mice and Humans: From No Naive Expectations to Foggy Memories. J Immunol (2014) 193 (6):2622-9. doi: 10.4049/jimmunol.1401174

41. Dugan HL, Henry C, Wilson PC. Aging and Influenza Vaccine-Induced Immunity. Cell Immunol (2020) 348:103998. doi: 10.1016/j.cellimm.2019.103998

42. Qi Q, Zhang DW, Weyand CM, Goronzy JJ. Mechanisms Shaping the Naive $\mathrm{T}$ Cell Repertoire in the Elderly - Thymic Involution or Peripheral Homeostatic Proliferation? Exp Gerontol (2014) 54:71-4. doi: 10.1016/ j.exger.2014.01.005

43. Boucher N, Dufeu-Duchesne T, Vicaut E, Farge D, Effros RB, Schachter F. CD28 Expression in T Cell Aging and Human Longevity. Exp Gerontol (1998) 33(3):267-82. doi: 10.1016/S0531-5565(97)00132-0

44. Marcotte R, Lacelle C, Wang E. Senescent Fibroblasts Resist Apoptosis by Downregulating Caspase-3. Mech Ageing Dev (2004) 125(10-11):777-83. doi: 10.1016/j.mad.2004.07.007

45. Shay JW, Wright WE. Senescence and Immortalization: Role of Telomeres and Telomerase. Carcinogenesis (2005) 26(5):867-74. doi: 10.1093/carcin/ bgh296

46. Vallejo AN. CD28 Extinction in Human T Cells: Altered Functions and the Program of T-cell Senescence. Immunol Rev (2005) 205:158-69. doi: 10.1111/j.0105-2896.2005.00256.x

47. Murata Y, Wakoh T, Uekawa N, Sugimoto M, Asai A, Miyazaki T, et al. Death-Associated Protein 3 Regulates Cellular Senescence Through Oxidative Stress Response. FEBS Lett (2006) 580(26):6093-9. doi: 10.1016/ j.febslet.2006.10.004

48. Takahashi A, Ohtani N, Yamakoshi K, Iida S, Tahara H, Nakayama K, et al. Mitogenic Signalling and the P16ink4a-Rb Pathway Cooperate to Enforce Irreversible Cellular Senescence. Nat Cell Biol (2006) 8(11):1291-7. doi: $10.1038 /$ ncb1491

49. Demidenko ZN, Blagosklonny MV. Growth Stimulation Leads to Cellular Senescence When the Cell Cycle is Blocked. Cell Cycle (2008) 7(21):3355-61. doi: $10.4161 /$ cc.7.21.6919

50. Henson SM, Akbar AN. KLRG1-More Than a Marker for T Cell Senescence. Age (Dordr) (2009) 31(4):285-91. doi: 10.1007/s11357-009-9100-9

51. Pangrazzi L, Weinberger B. T Cells, Aging and Senescence. Exp Gerontol (2020) 134:110887. doi: 10.1016/j.exger.2020.110887

52. Zhao Y, Shao Q, Peng G. Exhaustion and Senescence: Two Crucial Dysfunctional States of T Cells in the Tumor Microenvironment. Cell Mol Immunol (2020) 17(1):27-35. doi: 10.1038/s41423-019-0344-8

53. He S, Sharpless NE. Senescence in Health and Disease. Cell (2017) 169 (6):1000-11. doi: 10.1016/j.cell.2017.05.015

54. Decman V, Laidlaw BJ, Dimenna LJ, Abdulla S, Mozdzanowska K, Erikson J, et al. Cell-Intrinsic Defects in the Proliferative Response of Antiviral Memory CD8 T Cells in Aged Mice Upon Secondary Infection. J Immunol (2010) 184(9):5151-9. doi: 10.4049/jimmunol.0902063

55. Tahir S, Fukushima Y, Sakamoto K, Sato K, Fujita H, Inoue J, et al. A Cd153 $+\mathrm{Cd} 4+\mathrm{T}$ Follicular Cell Population With Cell-Senescence Features Plays a Crucial Role in Lupus Pathogenesis Via Osteopontin Production. J Immunol (2015) 194(12):5725-35. doi: 10.4049/jimmunol.1500319

56. Ferrucci L, Fabbri E. Inflammageing: Chronic Inflammation in Ageing, Cardiovascular Disease, and Frailty. Nat Rev Cardiol (2018) 15(9):505-22. doi: 10.1038/s41569-018-0064-2

57. Franceschi C, Bonafe M, Valensin S, Olivieri F, De Luca M, Ottaviani E, et al. Inflamm-Aging. An Evolutionary Perspective on Immunosenescence. Ann N Y Acad Sci (2000) 908:244-54. doi: 10.1111/j.1749-6632.2000.tb06651.x

58. Chaleckis R, Murakami I, Takada J, Kondoh H, Yanagida M. Individual Variability in Human Blood Metabolites Identifies Age-Related Differences. Proc Natl Acad Sci USA (2016) 113(16):4252-9. doi: 10.1073/pnas.1603023113
59. Milan-Mattos JC, Anibal FF, Perseguini NM, Minatel V, Rehder-Santos P, Castro $\mathrm{CA}$, et al. Effects of Natural Aging and Gender on Pro-Inflammatory Markers. Braz J Med Biol Res (2019) 52(9):e8392. doi: 10.1590/1414-431x20198392

60. Franceschi C, Campisi J. Chronic Inflammation (Inflammaging) and its Potential Contribution to Age-Associated Diseases. J Gerontol A Biol Sci Med Sci (2014) 69(Suppl 1):S4-9. doi: 10.1093/gerona/glu057

61. Mejias NH, Martinez CC, Stephens ME, de Rivero Vaccari JP. Contribution of the Inflammasome to Inflammaging. J Inflammation (Lond) (2018) 15:23. doi: 10.1186/s12950-018-0198-3

62. Ciabattini A, Nardini C, Santoro F, Garagnani P, Franceschi C, Medaglini D. Vaccination in the Elderly: The Challenge of Immune Changes With Aging. Semin Immunol (2018) 40:83-94. doi: 10.1016/j.smim.2018.10.010

63. Chung HY, Cesari M, Anton S, Marzetti E, Giovannini S, Seo AY, et al. Molecular Inflammation: Underpinnings of Aging and Age-Related Diseases. Ageing Res Rev (2009) 8(1):18-30. doi: 10.1016/j.arr.2008.07.002

64. Franceschi C, Salvioli S, Garagnani P, de Eguileor M, Monti D, Capri M. Immunobiography and the Heterogeneity of Immune Responses in the Elderly: A Focus on Inflammaging and Trained Immunity. Front Immunol (2017) 8:982. doi: 10.3389/fimmu.2017.00982

65. Franceschi C, Garagnani P, Morsiani C, Conte M, Santoro A, Grignolio A, et al. The Continuum of Aging and Age-Related Diseases: Common Mechanisms But Different Rates. Front Med (Lausanne) (2018) 5:61. doi: 10.3389/fmed.2018.00061

66. Calder PC, Bosco N, Bourdet-Sicard R, Capuron L, Delzenne N, Dore J, et al. Health Relevance of the Modification of Low Grade Inflammation in Ageing (Inflammageing) and the Role of Nutrition. Ageing Res Rev (2017) 40:95119. doi: 10.1016/j.arr.2017.09.001

67. Franceschi C, Garagnani P, Parini P, Giuliani C, Santoro A. Inflammaging: A New Immune-Metabolic Viewpoint for Age-Related Diseases. Nat Rev Endocrinol (2018) 14(10):576-90. doi: 10.1038/s41574-018-0059-4

68. Furman D, Campisi J, Verdin E, Carrera-Bastos P, Targ S, Franceschi C, et al. Chronic Inflammation in the Etiology of Disease Across the Life Span. Nat Med (2019) 25(12):1822-32. doi: 10.1038/s41591-019-0675-0

69. Rea IM, Gibson DS, McGilligan V, McNerlan SE, Alexander HD, Ross OA. Age and Age-Related Diseases: Role of Inflammation Triggers and Cytokines. Front Immunol (2018) 9:586. doi: 10.3389/fimmu.2018.00586

70. Bektas A, Schurman SH, Sen R, Ferrucci L. Human T Cell Immunosenescence and Inflammation in Aging. J Leukoc Biol (2017) 102(4):977-88. doi: 10.1189/ jlb.3RI0716-335R

71. Coppe JP, Patil CK, Rodier F, Sun Y, Munoz DP, Goldstein J, et al. Senescence-Associated Secretory Phenotypes Reveal Cell-Nonautonomous Functions of Oncogenic RAS and the p53 Tumor Suppressor. PLoS Biol (2008) 6(12):2853-68. doi: 10.1371/journal.pbio.0060301

72. Fulop T, Larbi A, Dupuis G, Le Page A, Frost EH, Cohen AA, et al. Immunosenescence and Inflamm-Aging as Two Sides of the Same Coin: Friends or Foes? Front Immunol (2017) 8:1960. doi: 10.3389/fimmu.2017.01960

73. Wikby A, Nilsson BO, Forsey R, Thompson J, Strindhall J, Lofgren S, et al. The Immune Risk Phenotype is Associated With IL-6 in the Terminal Decline Stage: Findings From the Swedish NONA Immune Longitudinal Study of Very Late Life Functioning. Mech Ageing Dev (2006) 127(8):695704. doi: 10.1016/j.mad.2006.04.003

74. Klenerman P, Oxenius A. T Cell Responses to Cytomegalovirus. Nat Rev Immunol (2016) 16(6):367-77. doi: 10.1038/nri.2016.38

75. Di Benedetto S, Derhovanessian E, Steinhagen-Thiessen E, Goldeck D, Muller L, Pawelec G. Impact of Age, Sex and CMV-infection on Peripheral T Cell Phenotypes: Results From the Berlin Base-II Study. Biogerontology (2015) 16(5):631-43. doi: 10.1007/s10522-015-9563-2

76. Spyridopoulos I, Martin-Ruiz C, Hilkens C, Yadegarfar ME, Isaacs J, Jagger C, et al. CMV Seropositivity and T-cell Senescence Predict Increased Cardiovascular Mortality in Octogenarians: Results From the Newcastle 85+ Study. Aging Cell (2016) 15(2):389-92. doi: 10.1111/acel.12430

77. Ouyang Q, Wagner WM, Wikby A, Walter S, Aubert G, Dodi AI, et al. Large Numbers of Dysfunctional CD8+ T Lymphocytes Bearing Receptors for a Single Dominant CMV Epitope in the Very Old. J Clin Immunol (2003) 23 (4):247-57. doi: 10.1023/A:1024580531705

78. Bauer ME, Fuente Mde L. The Role of Oxidative and Inflammatory Stress and Persistent Viral Infections in Immunosenescence. Mech Ageing Dev (2016) 158:27-37. doi: 10.1016/j.mad.2016.01.001 
79. Goronzy JJ, Weyand CM. Understanding Immunosenescence to Improve Responses to Vaccines. Nat Immunol (2013) 14(5):428-36. doi: 10.1038/ ni. 2588

80. Gibson KL, Wu YC, Barnett Y, Duggan O, Vaughan R, Kondeatis E, et al. BCell Diversity Decreases in Old Age and is Correlated With Poor Health Status. Aging Cell (2009) 8(1):18-25. doi: 10.1111/j.1474-9726.2008.00443.x

81. Frasca D, Diaz A, Romero M, Landin AM, Blomberg BB. High TNF-alpha Levels in Resting B Cells Negatively Correlate With Their Response. Exp Gerontol (2014) 54:116-22. doi: 10.1016/j.exger.2014.01.004

82. Frasca D, Blomberg BB, Garcia D, Keilich SR, Haynes L. Age-Related Factors That Affect B Cell Responses to Vaccination in Mice and Humans. Immunol Rev (2020) 296(1):142-54. doi: 10.1111/imr.12864

83. Hope-Simpson RE. The Nature of Herpes Zoster: A Long-Term Study and a New Hypothesis. Proc R Soc Med (1965) 58:9-20. doi: 10.1177/ 003591576505800106

84. Gershon AA, Breuer J, Cohen JI, Cohrs RJ, Gershon MD, Gilden D, et al. Varicella Zoster Virus Infection. Nat Rev Dis Primers (2015) 1:15016. doi: $10.1038 /$ nrdp. 2015.16

85. Markus A, Lebenthal-Loinger I, Yang IH, Kinchington PR, Goldstein RS. An In Vitro Model of Latency and Reactivation of Varicella Zoster Virus in Human Stem Cell-Derived Neurons. PLoS Pathog (2015) 11(6):e1004885. doi: 10.1371/journal.ppat.1004885

86. Depledge DP, Sadaoka T, Ouwendijk WJD. Molecular Aspects of VaricellaZoster Virus Latency. Viruses (2018) 10(7):349. doi: 10.3390/v10070349

87. Ouwendijk WJD, van Veen S, Mehraban T, Mahalingam R, Verjans G. Simian Varicella Virus Infects Enteric Neurons and Alpha4beta7 IntegrinExpressing Gut-Tropic T-Cells in Nonhuman Primates. Viruses (2018) 10 (4):156. doi: 10.3390/v10040156

88. Huning S, von Ducker L, Kohl WK, Nashan D. Therapy of Herpes Zoster and Postherpetic Neuralgia. Hautarzt (2019) 70(8):645-56. doi: 10.1007/ s00105-019-4446-0

89. Looney RJ, Falsey A, Campbell D, Torres A, Kolassa J, Brower C, et al. Role of Cytomegalovirus in the T Cell Changes Seen in Elderly Individuals. Clin Immunol (1999) 90(2):213-9. doi: 10.1006/clim.1998.4638

90. Cannon MJ, Schmid DS, Hyde TB. Review of Cytomegalovirus Seroprevalence and Demographic Characteristics Associated With Infection. Rev Med Virol (2010) 20(4):202-13. doi: 10.1002/rmv.655

91. Nikolich-Zugich J, Goodrum F, Knox K, Smithey MJ. Known Unknowns: How Might the Persistent Herpesvirome Shape Immunity and Aging? Curr Opin Immunol (2017) 48:23-30. doi: 10.1016/j.coi.2017.07.011

92. Komatsu H, Sierro S, A VC, Klenerman P. Population Analysis of Antiviral T Cell Responses Using MHC Class I-peptide Tetramers. Clin Exp Immunol (2003) 134(1):9-12. doi: 10.1046/j.1365-2249.2003.02266.x

93. Schober K, Voit F, Grassmann S, Muller TR, Eggert J, Jarosch S, et al. Reverse TCR Repertoire Evolution Toward Dominant Low-Affinity Clones During Chronic CMV Infection. Nat Immunol (2020) 21(4):434-41. doi: 10.1038/ s41590-020-0628-2

94. Pawelec G, Akbar A, Beverley P, Caruso C, Derhovanessian E, Fulop T, et al. Immunosenescence and Cytomegalovirus: Where do We Stand After a Decade? Immun Ageing (2010) 7:13. doi: 10.1186/1742-4933-7-13

95. Moss P. The Emerging Role of Cytomegalovirus in Driving Immune Senescence: A Novel Therapeutic Opportunity for Improving Health in the Elderly. Curr Opin Immunol (2010) 22(4):529-34. doi: 10.1016/j.coi.2010.07.001

96. Khan N, Shariff N, Cobbold M, Bruton R, Ainsworth JA, Sinclair AJ, et al. Cytomegalovirus Seropositivity Drives the CD8 T Cell Repertoire Toward Greater Clonality in Healthy Elderly Individuals. J Immunol (2002) 169 (4):1984-92. doi: 10.4049/jimmunol.169.4.1984

97. Thompson WW, Shay DK, Weintraub E, Brammer L, Cox N, Anderson LJ, et al. Mortality Associated With Influenza and Respiratory Syncytial Virus in the United States. JAMA (2003) 289(2):179-86. doi: 10.1001/jama.289.2.179

98. Falsey AR, Hennessey PA, Formica MA, Cox C, Walsh EE. Respiratory Syncytial Virus Infection in Elderly and High-Risk Adults. $N$ Engl J Med (2005) 352(17):1749-59. doi: 10.1056/NEJMoa043951

99. Frasca D, Blomberg BB. Aging Induces B Cell Defects and Decreased Antibody Responses to Influenza Infection and Vaccination. Immun Ageing (2020) 17(1):37. doi: 10.1186/s12979-020-00210-z

100. Iuliano AD, Roguski KM, Chang HH, Muscatello DJ, Palekar R, Tempia S, et al. Estimates of Global Seasonal Influenza-Associated Respiratory
Mortality: A Modelling Study. Lancet (2018) 391(10127):1285-300. doi: 10.1016/S0140-6736(17)33293-2

101. Wong CK, Smith CA, Sakamoto K, Kaminski N, Koff JL, Goldstein DR. Aging Impairs Alveolar Macrophage Phagocytosis and Increases InfluenzaInduced Mortality in Mice. J Immunol (2017) 199(3):1060-8. doi: 10.4049/ jimmunol.1700397

102. Ackerson B, Tseng HF, Sy LS, Solano Z, Slezak J, Luo Y, et al. Severe Morbidity and Mortality Associated With Respiratory Syncytial Virus Versus Influenza Infection in Hospitalized Older Adults. Clin Infect Dis (2019) 69(2):197-203. doi: 10.1093/cid/ciy991

103. Domnich A, Arata L, Amicizia D, Puig-Barbera J, Gasparini R, Panatto D. Effectiveness of MF59-adjuvanted Seasonal Influenza Vaccine in the Elderly: A Systematic Review and Meta-Analysis. Vaccine (2017) 35(4):513-20. doi: 10.1016/j.vaccine.2016.12.011

104. Dunkle LM, Izikson R, Patriarca P, Goldenthal KL, Muse D, Callahan J, et al. Efficacy of Recombinant Influenza Vaccine in Adults 50 Years of Age or Older. N Engl J Med (2017) 376(25):2427-36. doi: 10.1056/NEJMoa1608862

105. Chang LJ, Meng Y, Janosczyk H, Landolfi V, Talbot HK, Group QHDS. Safety and Immunogenicity of High-Dose Quadrivalent Influenza Vaccine in Adults >/=65years of Age: A Phase 3 Randomized Clinical Trial. Vaccine (2019) 37(39):5825-34. doi: 10.1016/j.vaccine.2019.08.016

106. Smetana J, Chlibek R, Shaw J, Splino M, Prymula R. Influenza Vaccination in the Elderly. Hum Vaccin Immunother (2018) 14(3):540-9. doi: 10.1080/ 21645515.2017.1343226

107. Williams K, Bastian AR, Feldman RA, Omoruyi E, de Paepe E, Hendriks J, et al. Phase 1 Safety and Immunogenicity Study of a Respiratory Syncytial Virus Vaccine With an Adenovirus 26 Vector Encoding Prefusion F (Ad26.RSV.preF) in Adults Aged $>/=60$ Years. J Infect Dis (2020) 222 (6):979-88. doi: 10.1093/infdis/jiaa193

108. Cicconi P, Jones C, Sarkar E, Silva-Reyes L, Klenerman P, de Lara C, et al. First-in-Human Randomized Study to Assess the Safety and Immunogenicity of an Investigational Respiratory Syncytial Virus (Rsv) Vaccine Based on Chimpanzee-Adenovirus-155 Viral Vector-Expressing Rsv Fusion, Nucleocapsid, and Antitermination Viral Proteins in Healthy Adults. Clin Infect Dis (2020) 70(10):2073-81. doi: 10.1093/cid/ciz653

109. Langley JM, MacDonald LD, Weir GM, MacKinnon-Cameron D, Ye L, McNeil S, et al. A Respiratory Syncytial Virus Vaccine Based on the Small Hydrophobic Protein Ectodomain Presented With a Novel Lipid-Based Formulation is Highly Immunogenic and Safe in Adults: A First-inHumans Study. J Infect Dis (2018) 218(3):378-87. doi: 10.1093/infdis/jiy177

110. Mazur NI, Higgins D, Nunes MC, Melero JA, Langedijk AC, Horsley N, et al. The Respiratory Syncytial Virus Vaccine Landscape: Lessons From the Graveyard and Promising Candidates. Lancet Infect Dis (2018) 18(10): e295-311. doi: 10.1016/S1473-3099(18)30292-5

111. Aiello A, Farzaneh F, Candore G, Caruso C, Davinelli S, Gambino CM, et al. Immunosenescence and Its Hallmarks: How to Oppose Aging Strategically? A Review of Potential Options for Therapeutic Intervention. Front Immunol (2019) 10:2247. doi: 10.3389/fimmu.2019.02247

112. Mildner A, Jung S. Development and Function of Dendritic Cell Subsets. Immunity (2014) 40(5):642-56. doi: 10.1016/j.immuni.2014.04.016

113. Balan S, Saxena M, Bhardwaj N. Dendritic Cell Subsets and Locations. Int Rev Cell Mol Biol (2019) 348:1-68. doi: 10.1016/bs.ircmb.2019.07.004

114. Qian C, Cao X. Dendritic Cells in the Regulation of Immunity and Inflammation. Semin Immunol (2018) 35:3-11. doi: 10.1016/j.smim.2017. 12.002

115. Basit F, Mathan T, Sancho D, de Vries IJM. Human Dendritic Cell Subsets Undergo Distinct Metabolic Reprogramming for Immune Response. Front Immunol (2018) 9:2489. doi: 10.3389/fimmu.2018.02489

116. Swiecki M, Colonna M. The Multifaceted Biology of Plasmacytoid Dendritic Cells. Nat Rev Immunol (2015) 15(8):471-85. doi: 10.1038/nri3865

117. Merad M, Sathe P, Helft J, Miller J, Mortha A. The Dendritic Cell Lineage: Ontogeny and Function of Dendritic Cells and Their Subsets in the Steady State and the Inflamed Setting. Annu Rev Immunol (2013) 31:563-604. doi: 10.1146/annurev-immunol-020711-074950

118. Hildner K, Edelson BT, Purtha WE, Diamond M, Matsushita H, Kohyama $\mathrm{M}$, et al. Batf3 Deficiency Reveals a Critical Role for CD8alpha+ Dendritic Cells in Cytotoxic T Cell Immunity. Science (2008) 322(5904):1097-100. doi: 10.1126/science.1164206 
119. Della Bella S, Bierti L, Presicce P, Arienti R, Valenti M, Saresella M, et al. Peripheral Blood Dendritic Cells and Monocytes are Differently Regulated in the Elderly. Clin Immunol (2007) 122(2):220-8. doi: 10.1016/j.clim.2006.09.012

120. Jing Y, Shaheen E, Drake RR, Chen N, Gravenstein S, Deng Y. Aging is Associated With a Numerical and Functional Decline in Plasmacytoid Dendritic Cells, Whereas Myeloid Dendritic Cells are Relatively Unaltered in Human Peripheral Blood. Hum Immunol (2009) 70(10):777-84. doi: 10.1016/j.humimm.2009.07.005

121. Sridharan A, Esposo M, Kaushal K, Tay J, Osann K, Agrawal S, et al. AgeAssociated Impaired Plasmacytoid Dendritic Cell Functions Lead to Decreased CD4 and CD8 T Cell Immunity. Age (Dordr) (2011) 33(3):36376. doi: 10.1007/s11357-010-9191-3

122. Metcalf TU, Cubas RA, Ghneim K, Cartwright MJ, Grevenynghe JV, Richner JM, et al. Global Analyses Revealed Age-Related Alterations in Innate Immune Responses After Stimulation of Pathogen Recognition Receptors. Aging Cell (2015) 14(3):421-32. doi: 10.1111/acel.12320

123. Agrawal A, Agrawal S, Cao JN, Su H, Osann K, Gupta S. Altered Innate Immune Functioning of Dendritic Cells in Elderly Humans: A Role of Phosphoinositide 3-Kinase-Signaling Pathway. J Immunol (2007) 178 (11):6912-22. doi: 10.4049/jimmunol.178.11.6912

124. Agrawal A, Tay J, Ton S, Agrawal S, Gupta S. Increased Reactivity of Dendritic Cells From Aged Subjects to Self-Antigen, the Human DNA. J Immunol (2009) 182(2):1138-45. doi: 10.4049/jimmunol.182.2.1138

125. van Duin D, Mohanty S, Thomas V, Ginter S, Montgomery RR, Fikrig E, et al. Age-Associated Defect in Human TLR-1/2 Function. J Immunol (2007) 178(2):970-5. doi: 10.4049/jimmunol.178.2.970

126. Panda A, Qian F, Mohanty S, van Duin D, Newman FK, Zhang L, et al. AgeAssociated Decrease in TLR Function in Primary Human Dendritic Cells Predicts Influenza Vaccine Response. J Immunol (2010) 184(5):2518-27. doi: 10.4049/jimmunol.0901022

127. Rosenstiel P, Derer S, Till A, Hasler R, Eberstein H, Bewig B, et al. Systematic Expression Profiling of Innate Immune Genes Defines a Complex Pattern of Immunosenescence in Peripheral and Intestinal Leukocytes. Genes Immun (2008) 9(2):103-14. doi: 10.1038/sj.gene.6364454

128. Gardner JK, Mamotte CDS, Jackaman C, Nelson DJ. Modulation of Dendritic Cell and T Cell Cross-Talk During Aging: The Potential Role of Checkpoint Inhibitory Molecules. Ageing Res Rev (2017) 38:40-51. doi: 10.1016/j.arr.2017.07.002

129. Cao JN, Agrawal A, Sharman E, Jia Z, Gupta S. Alterations in Gene Array Patterns in Dendritic Cells From Aged Humans. PLoS One (2014) 9(9): e106471. doi: 10.1371/journal.pone.0106471

130. Wong C, Goldstein DR. Impact of Aging on Antigen Presentation Cell Function of Dendritic Cells. Curr Opin Immunol (2013) 25(4):535-41. doi: 10.1016/j.coi.2013.05.016

131. Qu C, Brinck-Jensen NS, Zang M, Chen K. Monocyte-Derived Dendritic Cells: Targets as Potent Antigen-Presenting Cells for the Design of Vaccines Against Infectious Diseases. Int J Infect Dis (2014) 19:1-5. doi: 10.1016/ j.ijid.2013.09.023

132. Worbs T, Hammerschmidt SI, Forster R. Dendritic Cell Migration in Health and Disease. Nat Rev Immunol (2017) 17(1):30-48. doi: 10.1038/nri.2016.116

133. Aydar Y, Balogh P, Tew JG, Szakal AK. Altered Regulation of Fc Gamma RII on Aged Follicular Dendritic Cells Correlates With Immunoreceptor Tyrosine-Based Inhibition Motif Signaling in B Cells and Reduced Germinal Center Formation. J Immunol (2003) 171(11):5975-87. doi: 10.4049/jimmunol.171.11.5975

134. Zhang L, Wang CC. Inflammatory Response of Macrophages in Infection. Hepatobiliary Pancreat Dis Int (2014) 13(2):138-52. doi: 10.1016/S14993872(14)60024-2

135. Vetvicka V, Tlaskalova-Hogenova H, Pospisil M. Impaired Antigen Presenting Function of Macrophages From Aged Mice. Immunol Invest (1985) 14(2):105-14. doi: 10.3109/08820138509042005

136. Plowden J, Renshaw-Hoelscher M, Gangappa S, Engleman C, Katz JM, Sambhara S. Impaired Antigen-Induced CD8+ T Cell Clonal Expansion in Aging is Due to Defects in Antigen Presenting Cell Function. Cell Immunol (2004) 229(2):86-92. doi: 10.1016/j.cellimm.2004.07.001

137. Mahbub S, Deburghgraeve CR, Kovacs EJ. Advanced Age Impairs Macrophage Polarization. J Interferon Cytokine Res (2012) 32(1):18-26. doi: $10.1089 /$ jir.2011.0058
138. Becker L, Nguyen L, Gill J, Kulkarni S, Pasricha PJ, Habtezion A. AgeDependent Shift in Macrophage Polarisation Causes InflammationMediated Degeneration of Enteric Nervous System. Gut (2018) 67(5):82736. doi: 10.1136/gutjnl-2016-312940

139. Cui CY, Driscoll RK, Piao Y, Chia CW, Gorospe M, Ferrucci L. Skewed Macrophage Polarization in Aging Skeletal Muscle. Aging Cell (2019) 18(6): e13032. doi: 10.1111/acel.13032

140. Lumeng CN, Liu J, Geletka L, Delaney C, Delproposto J, Desai A, et al. Aging is Associated With an Increase in T Cells and Inflammatory Macrophages in Visceral Adipose Tissue. J Immunol (2011) 187(12):6208-16. doi: 10.4049/ jimmunol.1102188

141. Wang Y, Wehling-Henricks M, Samengo G, Tidball JG. Increases of M2a Macrophages and Fibrosis in Aging Muscle are Influenced by Bone Marrow Aging and Negatively Regulated by Muscle-Derived Nitric Oxide. Aging Cell (2015) 14(4):678-88. doi: 10.1111/acel.12350

142. Linehan E, Dombrowski Y, Snoddy R, Fallon PG, Kissenpfennig A, Fitzgerald DC. Aging Impairs Peritoneal But Not Bone Marrow-Derived Macrophage Phagocytosis. Aging Cell (2014) 13(4):699-708. doi: 10.1111/acel.12223

143. Seidler S, Zimmermann HW, Bartneck M, Trautwein C, Tacke F. AgeDependent Alterations of Monocyte Subsets and Monocyte-Related Chemokine Pathways in Healthy Adults. BMC Immunol (2010) 11:30. doi: 10.1186/1471-2172-11-30

144. Metcalf TU, Wilkinson PA, Cameron MJ, Ghneim K, Chiang C, Wertheimer AM, et al. Human Monocyte Subsets Are Transcriptionally and Functionally Altered in Aging in Response to Pattern Recognition Receptor Agonists. J Immunol (2017) 199(4):1405-17. doi: 10.4049/jimmunol.1700148

145. Qian F, Wang X, Zhang L, Chen S, Piecychna M, Allore H, et al. Age-Associated Elevation in TLR5 Leads to Increased Inflammatory Responses in the Elderly. Aging Cell (2012) 11(1):104-10. doi: 10.1111/j.1474-9726.2011.00759.x

146. Nyugen J, Agrawal S, Gollapudi S, Gupta S. Impaired Functions of Peripheral Blood Monocyte Subpopulations in Aged Humans. J Clin Immunol (2010) 30 (6):806-13. doi: 10.1007/s10875-010-9448-8

147. van Duin D, Allore HG, Mohanty S, Ginter S, Newman FK, Belshe RB, et al. Prevaccine Determination of the Expression of Costimulatory B7 Molecules in Activated Monocytes Predicts Influenza Vaccine Responses in Young and Older Adults. J Infect Dis (2007) 195(11):1590-7. doi: 10.1086/516788

148. Strohacker K, Breslin WL, Carpenter KC, McFarlin BK. Aged Mice Have Increased Inflammatory Monocyte Concentration and Altered Expression of Cell-Surface Functional Receptors. J Biosci (2012) 37(1):55-62. doi: 10.1007/ s12038-011-9169-z

149. Busse S, Steiner J, Alter J, Dobrowolny H, Mawrin C, Bogerts B, et al. Expression of HLA-DR, CD80, and CD86 in Healthy Aging and Alzheimer's Disease. J Alzheimers Dis (2015) 47(1):177-84. doi: 10.3233/JAD-150217

150. Herrero C, Sebastian C, Marques L, Comalada M, Xaus J, Valledor AF, et al. Immunosenescence of Macrophages: Reduced MHC Class II Gene Expression. Exp Gerontol (2002) 37(2-3):389-94. doi: 10.1016/S0531-5565 (01)00205-4

151. Villanueva JL, Solana R, Alonso MC, Pena J. Changes in the Expression of HLA-class II Antigens on Peripheral Blood Monocytes From Aged Humans. Dis Markers (1990) 8(2):85-91.

152. Herrero C, Marques L, Lloberas J, Celada A. IFN-Gamma-Dependent Transcription of MHC Class II IA is Impaired in Macrophages From Aged Mice. J Clin Invest (2001) 107(4):485-93. doi: 10.1172/JCI11696

153. Renshaw M, Rockwell J, Engleman C, Gewirtz A, Katz J, Sambhara S. Cutting Edge: Impaired Toll-like Receptor Expression and Function in Aging. J Immunol (2002) 169(9):4697-701. doi: 10.4049/jimmunol.169.9.4697

154. Hearps AC, Martin GE, Angelovich TA, Cheng WJ, Maisa A, Landay AL, et al. Aging is Associated With Chronic Innate Immune Activation and Dysregulation of Monocyte Phenotype and Function. Aging Cell (2012) 11 (5):867-75. doi: 10.1111/j.1474-9726.2012.00851.x

155. Amulic B, Cazalet C, Hayes GL, Metzler KD, Zychlinsky A. Neutrophil Function: From Mechanisms to Disease. Annu Rev Immunol (2012) 30:45989. doi: 10.1146/annurev-immunol-020711-074942

156. Adrover JM, Nicolas-Avila JA, Hidalgo A. Aging: A Temporal Dimension for Neutrophils. Trends Immunol (2016) 37(5):334-45. doi: 10.1016/j.it.2016.03.005

157. Ley K, Hoffman HM, Kubes P, Cassatella MA, Zychlinsky A, Hedrick CC, et al. Neutrophils: New Insights and Open Questions. Sci Immunol (2018) 3 (30):eaat4579. doi: 10.1126/sciimmunol.aat 4579 
158. Cossio I, Lucas D, Hidalgo A. Neutrophils as Regulators of the Hematopoietic Niche. Blood (2019) 133(20):2140-8. doi: 10.1182/blood-2018-10-844571

159. Schurink B, Roos E, Radonic T, Barbe E, Bouman CSC, de Boer HH, et al. Viral Presence and Immunopathology in Patients With Lethal COVID-19: A Prospective Autopsy Cohort Study. Lancet Microbe (2020) 1(7):e290-9. doi: 10.1016/S2666-5247(20)30144-0

160. Veras FP, Pontelli MC, Silva CM, Toller-Kawahisa JE, de Lima M, Nascimento DC, et al. Sars-CoV-2-triggered Neutrophil Extracellular Traps Mediate COVID-19 Pathology. J Exp Med (2020) 217(12): e20201129. doi: 10.1084/jem.20201129

161. Simell B, Vuorela A, Ekstrom N, Palmu A, Reunanen A, Meri S, et al. Aging Reduces the Functionality of Anti-Pneumococcal Antibodies and the Killing of Streptococcus Pneumoniae by Neutrophil Phagocytosis. Vaccine (2011) 29 (10):1929-34. doi: 10.1016/j.vaccine.2010.12.121

162. Lopes AB, Lopes LB, da Silveira Antunes RN, Fukasawa JT, de ACD, Calamita Z. Effects of Immunosenescence on the Lower Expression of Surface Molecules in Neutrophils and Lymphocytes. Curr Aging Sci (2018) 11(2):118-25. doi: 10.2174/1874609811666180605092234

163. Whyte MK, Meagher LC, MacDermot J, Haslett C. Impairment of Function in Aging Neutrophils is Associated With Apoptosis. J Immunol (1993) 150 (11):5124-34.

164. Tomay F, Wells K, Duong L, Tsu JW, Dye DE, Radley-Crabb HG, et al. Aged Neutrophils Accumulate in Lymphoid Tissues From Healthy Elderly Mice and Infiltrate T- and B-cell Zones. Immunol Cell Biol (2018) 96(8):831-40. doi: $10.1111 /$ imcb. 12046

165. Zhang D, Chen G, Manwani D, Mortha A, Xu C, Faith JJ, et al. Neutrophil Ageing is Regulated by the Microbiome. Nature (2015) 525(7570):528-32. doi: 10.1038/nature15367

166. Kovalenko EI, Boyko AA, Semenkov VF, Lutsenko GV, Grechikhina MV, Kanevskiy LM, et al. ROS Production, Intracellular HSP70 Levels and Their Relationship in Human Neutrophils: Effects of Age. Oncotarget (2014) 5 (23):11800-12. doi: 10.18632/oncotarget.2856

167. Nogueira-Neto J, Cardoso AS, Monteiro HP, Fonseca FL, Ramos LR, Junqueira VB, et al. Basal Neutrophil Function in Human Aging: Implications in Endothelial Cell Adhesion. Cell Biol Int (2016) 40(7):796802. doi: $10.1002 /$ cbin. 10618

168. Tseng CW, Kyme PA, Arruda A, Ramanujan VK, Tawackoli W, Liu GY. Innate Immune Dysfunctions in Aged Mice Facilitate the Systemic Dissemination of Methicillin-Resistant S. Aureus. PLoS One (2012) 7(7): e41454. doi: 10.1371/journal.pone.0041454

169. Xu F, Zhang C, Zou Z, Fan EKY, Chen L, Li Y, et al. Aging-Related Atg5 Defect Impairs Neutrophil Extracellular Traps Formation. Immunology (2017) 151(4):417-32. doi: 10.1111/imm.12740

170. van Deursen JM. The Role of Senescent Cells in Ageing. Nature (2014) 509 (7501):439-46. doi: 10.1038/nature13193

171. Antonangeli F, Zingoni A, Soriani A, Santoni A. Senescent Cells: Living or Dying is a Matter of NK Cells. J Leukoc Biol (2019) 105(6):1275-83. doi: 10.1002/JLB.MR0718-299R

172. Campos C, Pera A, Lopez-Fernandez I, Alonso C, Tarazona R, Solana R. Proinflammatory Status Influences NK Cells Subsets in the Elderly. Immunol Lett (2014) 162(1 Pt B):298-302. doi: 10.1016/j.imlet.2014.06.015

173. Brighton PJ, Maruyama Y, Fishwick K, Vrljicak P, Tewary S, Fujihara R, et al. Clearance of Senescent Decidual Cells by Uterine Natural Killer Cells in Cycling Human Endometrium. Elife (2017) 6:e31274. doi: 10.7554/ eLife.31274

174. Mace EM, Orange JS. Emerging Insights Into Human Health and NK Cell Biology From the Study of NK Cell Deficiencies. Immunol Rev (2019) 287 (1):202-25. doi: 10.1111/imr.12725

175. Cook KD, Waggoner SN, Whitmire JK. NK Cells and Their Ability to Modulate T Cells During Virus Infections. Crit Rev Immunol (2014) 34 (5):359-88. doi: 10.1615/CritRevImmunol.2014010604

176. Vivier E, Tomasello E, Baratin M, Walzer T, Ugolini S. Functions of Natural Killer Cells. Nat Immunol (2008) 9(5):503-10. doi: 10.1038/ni1582

177. Sun JC, Ugolini S, Vivier E. Immunological Memory Within the Innate Immune System. EMBO J (2014) 33(12):1295-303. doi: 10.1002/embj.201387651

178. Cording S, Medvedovic J, Aychek T, Eberl G. Innate Lymphoid Cells in Defense, Immunopathology and Immunotherapy. Nat Immunol (2016) 17 (7):755-7. doi: 10.1038/ni.3448
179. Shehata HM, Hoebe K, Chougnet CA. The Aged Nonhematopoietic Environment Impairs Natural Killer Cell Maturation and Function. Aging Cell (2015) 14(2):191-9. doi: 10.1111/acel.12303

180. Hazeldine J, Lord JM. The Impact of Ageing on Natural Killer Cell Function and Potential Consequences for Health in Older Adults. Ageing Res Rev (2013) 12(4):1069-78. doi: 10.1016/j.arr.2013.04.003

181. Le Garff-Tavernier M, Beziat V, Decocq J, Siguret V, Gandjbakhch F, Pautas E, et al. Human NK Cells Display Major Phenotypic and Functional Changes Over the Life Span. Aging Cell (2010) 9(4):527-35. doi: 10.1111/j.14749726.2010.00584.x

182. Chidrawar SM, Khan N, Chan YL, Nayak L, Moss PA. Ageing is Associated With a Decline in Peripheral Blood CD56bright NK Cells. Immun Ageing (2006) 3:10. doi: 10.1186/1742-4933-3-10

183. Hazeldine J, Hampson P, Lord JM. Reduced Release and Binding of Perforin At the Immunological Synapse Underlies the Age-Related Decline in Natural Killer Cell Cytotoxicity. Aging Cell (2012) 11(5):751-9. doi: 10.1111/j.14749726.2012.00839.x

184. Solana C, Tarazona R, Solana R. Immunosenescence of Natural Killer Cells, Inflammation, and Alzheimer's Disease. Int J Alzheimers Dis 2018 (2018) p:3128758. doi: 10.1155/2018/3128758

185. Kumar BV, Connors TJ, Farber DL. Human T Cell Development, Localization, and Function Throughout Life. Immunity (2018) 48(2):20213. doi: 10.1016/j.immuni.2018.01.007

186. George AJ, Ritter MA. Thymic Involution With Ageing: Obsolescence or Good Housekeeping? Immunol Today (1996) 17(6):267-72. doi: 10.1016/ 0167-5699(96)80543-3

187. Aw D, Palmer DB. The Origin and Implication of Thymic Involution. Aging Dis (2011) 2(5):437-43.

188. Thapa P, Farber DL. The Role of the Thymus in the Immune Response. Thorac Surg Clin (2019) 29(2):123-31. doi: 10.1016/j.thorsurg.2018.12.001

189. Halnon NJ, Jamieson B, Plunkett M, Kitchen CM, Pham T, Krogstad P. Thymic Function and Impaired Maintenance of Peripheral T Cell Populations in Children With Congenital Heart Disease and Surgical Thymectomy. Pediatr Res (2005) 57(1):42-8. doi: 10.1203/01.PDR.0000147735.19342.DE

190. Sauce D, Larsen M, Fastenackels S, Duperrier A, Keller M, GrubeckLoebenstein B, et al. Evidence of Premature Immune Aging in Patients Thymectomized During Early Childhood. J Clin Invest (2009) 119(10):30708. doi: 10.1172/JCI39269

191. Murray JM, Kaufmann GR, Hodgkin PD, Lewin SR, Kelleher AD, Davenport MP, et al. Naive T Cells are Maintained by Thymic Output in Early Ages But by Proliferation Without Phenotypic Change After Age Twenty. Immunol Cell Biol (2003) 81(6):487-95. doi: 10.1046/j.1440-1711.2003.01191.x

192. den Braber I, Mugwagwa T, Vrisekoop N, Westera L, Mogling R, de Boer AB, et al. Maintenance of Peripheral Naive T Cells is Sustained by Thymus Output in Mice But Not Humans. Immunity (2012) 36(2):288-97. doi: 10.1016/j.immuni.2012.02.006

193. Goronzy JJ, Weyand CM. Mechanisms Underlying T Cell Ageing. Nat Rev Immunol (2019) 19(9):573-83. doi: 10.1038/s41577-019-0180-1

194. Cicin-Sain L, Messaoudi I, Park B, Currier N, Planer S, Fischer M, et al. Dramatic Increase in Naive T Cell Turnover is Linked to Loss of Naive T Cells From Old Primates. Proc Natl Acad Sci USA (2007) 104(50):19960-5. doi: 10.1073/pnas.0705905104

195. Thome JJ, Yudanin N, Ohmura Y, Kubota M, Grinshpun B, Sathaliyawala T, et al. Spatial Map of Human T Cell Compartmentalization and Maintenance Over Decades of Life. Cell (2014) 159(4):814-28. doi: 10.1016/j.cell.2014.10.026

196. Johnson PL, Yates AJ, Goronzy JJ, Antia R. Peripheral Selection Rather Than Thymic Involution Explains Sudden Contraction in Naive CD4 T-Cell Diversity With Age. Proc Natl Acad Sci USA (2012) 109(52):21432-7. doi: 10.1073/pnas. 1209283110

197. Kohlmeier JE, Ely KH, Connor LM, Roberts AD, Yager EJ, Woodland DL, et al. Beneficial and Detrimental Manifestations of Age on CD8 $+T$ Cell Memory to Respiratory Pathogens, in Handbook of Immunosenescence: Basic Understanding and Clinical Implications. Cham: Springer International Publishing (2017). p. 1-21. doi: 10.1007/978-3-319-64597-1_49-1

198. Alves AS, Bueno V. Immunosenescence: Participation of T Lymphocytes and Myeloid-Derived Suppressor Cells in Aging-Related Immune Response Changes. Einstein (Sao Paulo) (2019) 17(2):eRB4733. doi: 10.31744/ einstein_journal/2019RB4733 
199. Drobek A, Moudra A, Mueller D, Huranova M, Horkova V, Pribikova M, et al. Strong Homeostatic TCR Signals Induce Formation of Self-Tolerant Virtual Memory CD8 T Cells. EMBO J (2018) 37(14):e98518. doi: 10.15252/ embj.201798518

200. Quinn KM, Zaloumis SG, Cukalac T, Kan WT, Sng XY, Mirams M, et al. Heightened Self-Reactivity Associated With Selective Survival, But Not Expansion, of Naive Virus-Specific CD8+ T Cells in Aged Mice. Proc Natl Acad Sci USA (2016) 113(5):1333-8. doi: 10.1073/pnas.1525167113

201. Minato N, Hattori M, Hamazaki Y. Physiology and Pathology of T-cell Aging. Int Immunol (2020) 32(4):223-31. doi: 10.1093/intimm/dxaa006

202. Sato K, Kato A, Sekai M, Hamazaki Y, Minato N. Physiologic Thymic Involution Underlies Age-Dependent Accumulation of Senescence-Associated Cd4(+) T Cells. J Immunol (2017) 199(1):138-48. doi: 10.4049/jimmunol.1602005

203. Pulko V, Davies JS, Martinez C, Lanteri MC, Busch MP, Diamond MS, et al. Human Memory T Cells With a Naive Phenotype Accumulate With Aging and Respond to Persistent Viruses. Nat Immunol (2016) 17(8):966-75. doi: 10.1038/ni.3483

204. Gregg R, Smith CM, Clark FJ, Dunnion D, Khan N, Chakraverty R, et al. The Number of Human Peripheral Blood CD4+ CD25high Regulatory T Cells Increases With Age. Clin Exp Immunol (2005) 140(3):540-6. doi: 10.1111/ j.1365-2249.2005.02798.x

205. Walker LS. Treg and CTLA-4: Two Intertwining Pathways to Immune Tolerance. J Autoimmun (2013) 45:49-57. doi: 10.1016/j.jaut.2013.06.006

206. Mahnke K, Johnson TS, Ring S, Enk AH. Tolerogenic Dendritic Cells and Regulatory T Cells: A Two-Way Relationship. J Dermatol Sci (2007) 46 (3):159-67. doi: 10.1016/j.jdermsci.2007.03.002

207. Shahid Z, Kleppinger A, Gentleman B, Falsey AR, McElhaney JE. Clinical and Immunologic Predictors of Influenza Illness Among Vaccinated Older Adults. Vaccine (2010) 28(38):6145-51. doi: 10.1016/j.vaccine.2010.07.036

208. McElhaney JE, Ewen C, Zhou X, Kane KP, Xie D, Hager WD, et al. Granzyme B: Correlates With Protection and Enhanced CTL Response to Influenza Vaccination in Older Adults. Vaccine (2009) 27(18):2418-25. doi: 10.1016/j.vaccine.2009.01.136

209. Thiery J, Keefe D, Boulant S, Boucrot E, Walch M, Martinvalet D, et al. Perforin Pores in the Endosomal Membrane Trigger the Release of Endocytosed Granzyme B Into the Cytosol of Target Cells. Nat Immunol (2011) 12(8):770-7. doi: 10.1038/ni.2050

210. Boon AC, Fringuelli E, Graus YM, Fouchier RA, Sintnicolaas K, Iorio AM, et al. Influenza A Virus Specific T Cell Immunity in Humans During Aging. Virology (2002) 299(1):100-8. doi: 10.1006/viro.2002.1491

211. Brenchley JM, Karandikar NJ, Betts MR, Ambrozak DR, Hill BJ, Crotty LE, et al. Expression of CD57 Defines Replicative Senescence and AntigenInduced Apoptotic Death of CD8+ T Cells. Blood (2003) 101(7):2711-20. doi: 10.1182/blood-2002-07-2103

212. Czesnikiewicz-Guzik M, Lee WW, Cui D, Hiruma Y, Lamar DL, Yang ZZ, et al. T Cell Subset-Specific Susceptibility to Aging. Clin Immunol (2008) 127 (1):107-18. doi: 10.1016/j.clim.2007.12.002

213. Crooke SN, Ovsyannikova IG, Poland GA, Kennedy RB. Immunosenescence and Human Vaccine Immune Responses. Immun Ageing (2019) 16:25. doi: 10.1186/s12979-019-0164-9

214. Saurwein-Teissl M, Lung TL, Marx F, Gschosser C, Asch E, Blasko I, et al. Lack of Antibody Production Following Immunization in Old Age: Association With CD8(+)CD28(-) T Cell Clonal Expansions and an Imbalance in the Production of Th1 and Th2 Cytokines. J Immunol (2002) 168(11):5893-9. doi: 10.4049/jimmunol.168.11.5893

215. Hendriks J, Gravestein LA, Tesselaar K, van Lier RA, Schumacher TN, Borst J. CD27 is Required for Generation and Long-Term Maintenance of T Cell Immunity. Nat Immunol (2000) 1(5):433-40. doi: 10.1038/80877

216. Voehringer D, Koschella M, Pircher H. Lack of Proliferative Capacity of Human Effector and Memory T Cells Expressing Killer Cell Lectinlike Receptor G1 (Klrg1). Blood (2002) 100(10):3698-702. doi: 10.1182/blood-2002-02-0657

217. Yang OO, Lin H, Dagarag $\mathrm{M}, \mathrm{Ng} \mathrm{HL}$, Effros RB, Uittenbogaart $\mathrm{CH}$. Decreased Perforin and Granzyme B Expression in Senescent HIV-1specific Cytotoxic T Lymphocytes. Virology (2005) 332(1):16-9. doi: 10.1016/j.virol.2004.11.028

218. Coppe JP, Desprez PY, Krtolica A, Campisi J. The Senescence-Associated Secretory Phenotype: The Dark Side of Tumor Suppression. Annu Rev Pathol (2010) 5:99-118. doi: 10.1146/annurev-pathol-121808-102144
219. Wherry EJ, Kurachi M. Molecular and Cellular Insights Into T Cell Exhaustion. Nat Rev Immunol (2015) 15(8):486-99. doi: 10.1038/nri3862

220. Vescovini R, Telera A, Fagnoni FF, Biasini C, Medici MC, Valcavi P, et al. Different Contribution of EBV and CMV Infections in Very Long-Term Carriers to Age-Related Alterations of CD8+ T Cells. Exp Gerontol (2004) 39 (8):1233-43. doi: 10.1016/j.exger.2004.04.004

221. Brunner S, Herndler-Brandstetter D, Weinberger B, Grubeck-Loebenstein B. Persistent Viral Infections and Immune Aging. Ageing Res Rev (2011) 10 (3):362-9. doi: 10.1016/j.arr.2010.08.003

222. Fulop T, Larbi A, Pawelec G. Human T Cell Aging and the Impact of Persistent Viral Infections. Front Immunol (2013) 4:271. doi: 10.3389/fimmu.2013.00271

223. Forte E, Zhang Z, Thorp EB, Hummel M. Cytomegalovirus Latency and Reactivation: An Intricate Interplay With the Host Immune Response. Front Cell Infect Microbiol (2020) 10:130. doi: 10.3389/fcimb.2020.00130

224. Nussing S, Koay HF, Sant S, Loudovaris T, Mannering SI, Lappas M, et al. Divergent SATB1 Expression Across Human Life Span and Tissue Compartments. Immunol Cell Biol (2019) 97(5):498-511. doi: 10.1111/imcb.12233

225. Paez-Ribes M, Gonzalez-Gualda E, Doherty GJ, Munoz-Espin D. Targeting Senescent Cells in Translational Medicine. EMBO Mol Med (2019) 11(12): e10234. doi: 10.15252/emmm.201810234

226. Alter-Wolf S, Blomberg BB, Riley RL. Deviation of the B Cell Pathway in Senescent Mice is Associated With Reduced Surrogate Light Chain Expression and Altered Immature B Cell Generation, Phenotype, and Light Chain Expression. J Immunol (2009) 182(1):138-47. doi: 10.4049/ jimmunol.182.1.138

227. Ricci C, Cova M, Kang YS, Yang A, Rahmouni A, Scott WWJr., et al. Normal Age-Related Patterns of Cellular and Fatty Bone Marrow Distribution in the Axial Skeleton: MR Imaging Study. Radiology (1990) 177(1):83-8. doi: 10.1148/radiology.177.1.2399343

228. Chambers SM, Shaw CA, Gatza C, Fisk CJ, Donehower LA, Goodell MA. Aging Hematopoietic Stem Cells Decline in Function and Exhibit Epigenetic Dysregulation. PLoS Biol (2007) 5(8):e201. doi: 10.1371/journal.pbio.0050201

229. Bulati M, Buffa S, Candore G, Caruso C, Dunn-Walters DK, Pellicano M, et al. B Cells and Immunosenescence: A Focus on IgG+IgD-CD27- (Dn) B Cells in Aged Humans. Ageing Res Rev (2011) 10(2):274-84. doi: 10.1016/ j.arr.2010.12.002

230. Henry CJ, Casas-Selves M, Kim J, Zaberezhnyy V, Aghili L, Daniel AE, et al. Aging-Associated Inflammation Promotes Selection for Adaptive Oncogenic Events in B Cell Progenitors. J Clin Invest (2015) 125(12):4666-80. doi: 10.1172/JCI83024

231. Stephan RP, Lill-Elghanian DA, Witte PL. Development of B Cells in Aged Mice: Decline in the Ability of Pro-B Cells to Respond to IL-7 But Not to Other Growth Factors. J Immunol (1997) 158(4):1598-609.

232. Stephan RP, Reilly CR, Witte PL. Impaired Ability of Bone Marrow Stromal Cells to Support B-lymphopoiesis With Age. Blood (1998) 91(1):75-88. doi: 10.1182/blood.V91.1.75.75_75_88

233. Ratliff M, Alter S, Frasca D, Blomberg BB, Riley RL. In Senescence, AgeAssociated B Cells Secrete TNFalpha and Inhibit Survival of B-cell Precursors. Aging Cell (2013) 12(2):303-11. doi: 10.1111/acel.12055

234. Cancro MP. Age-Associated B Cells. Annu Rev Immunol (2020) 38:315-40. doi: 10.1146/annurev-immunol-092419-031130

235. Rubtsov AV, Rubtsova K, Fischer A, Meehan RT, Gillis JZ, Kappler JW, et al. Toll-Like Receptor 7 (TLR7)-Driven Accumulation of a Novel CD11c(+) BCell Population is Important for the Development of Autoimmunity. Blood (2011) 118(5):1305-15. doi: 10.1182/blood-2011-01-331462

236. Hao Y, O'Neill P, Naradikian MS, Scholz JL, Cancro MP. A B-cell Subset Uniquely Responsive to Innate Stimuli Accumulates in Aged Mice. Blood (2011) 118(5):1294-304. doi: 10.1182/blood-2011-01-330530

237. Riley RL, Khomtchouk K, Blomberg BB. Age-Associated B Cells (ABC) Inhibit B Lymphopoiesis and Alter Antibody Repertoires in Old Age. Cell Immunol (2017) 321:61-7. doi: 10.1016/j.cellimm.2017.04.008

238. Chang LY, Li Y, Kaplan DE. Hepatitis C Viraemia Reversibly Maintains Subset of Antigen-Specific T-bet+ Tissue-Like Memory B Cells. J Viral Hepat (2017) 24(5):389-96. doi: 10.1111/jvh.12659

239. Adlowitz DG, Barnard J, Biear JN, Cistrone C, Owen T, Wang W, et al. Expansion of Activated Peripheral Blood Memory B Cells in Rheumatoid Arthritis, Impact of B Cell Depletion Therapy, and Biomarkers of Response. PLoS One (2015) 10(6):e0128269. doi: 10.1371/journal.pone.0128269 
240. Sayegh CE, Quong MW, Agata Y, Murre C. E-Proteins Directly Regulate Expression of Activation-Induced Deaminase in Mature B Cells. Nat Immunol (2003) 4(6):586-93. doi: 10.1038/ni923

241. Frasca D, Diaz A, Romero M, Ferracci F, Blomberg BB. MicroRNAs miR-155 and Mir-16 Decrease AID and E47 in B Cells From Elderly Individuals. J Immunol (2015) 195(5):2134-40. doi: 10.4049/jimmunol.1500520

242. Kosco MH, Burton GF, Kapasi ZF, Szakal AK, Tew JG. Antibody-Forming Cell Induction During an Early Phase of Germinal Centre Development and its Delay With Ageing. Immunology (1989) 68(3):312-8.

243. Frasca D. Senescent B Cells in Aging and Age-Related Diseases: Their Role in the Regulation of Antibody Responses. Exp Gerontol (2018) 107:55-8. doi: 10.1016/j.exger.2017.07.002

244. Shankwitz K, Pallikkuth S, Sirupangi T, Kirk Kvistad D, Russel KB, Pahwa R, et al. Compromised Steady-State Germinal Center Activity With Age in Nonhuman Primates. Aging Cell (2020) 19(2):e13087. doi: 10.1111/ acel.13087

245. Pritz T, Lair J, Ban M, Keller M, Weinberger B, Krismer M, et al. Plasma Cell Numbers Decrease in Bone Marrow of Old Patients. Eur J Immunol (2015) 45(3):738-46. doi: 10.1002/eji.201444878

246. Han S, Yang K, Ozen Z, Peng W, Marinova E, Kelsoe G, et al. Enhanced Differentiation of Splenic Plasma Cells But Diminished Long-Lived HighAffinity Bone Marrow Plasma Cells in Aged Mice. J Immunol (2003) 170 (3):1267-73. doi: 10.4049/jimmunol.170.3.1267

247. Turner VM, Mabbott NA. Ageing Adversely Affects the Migration and Function of Marginal Zone B Cells. Immunology (2017) 151(3):349-62. doi: 10.1111/imm.12737

248. Weksler ME, Szabo P. The Effect of Age on the B-cell Repertoire. J Clin Immunol (2000) 20(4):240-9. doi: 10.1023/a:1006659401385

249. Ventura MT, Casciaro M, Gangemi S, Buquicchio R. Immunosenescence in Aging: Between Immune Cells Depletion and Cytokines Up-Regulation. Clin Mol Allergy (2017) 15:21. doi: 10.1186/s12948-017-0077-0

250. Listi F, Candore G, Modica MA, Russo M, Di Lorenzo G, Esposito-Pellitteri $\mathrm{M}$, et al. A Study of Serum Immunoglobulin Levels in Elderly Persons That Provides New Insights Into B Cell Immunosenescence. Ann N Y Acad Sci (2006) 1089:487-95. doi: 10.1196/annals.1386.013

251. Ma S, Wang C, Mao X, Hao Y. B Cell Dysfunction Associated With Aging and Autoimmune Diseases. Front Immunol (2019) 10:318. doi: 10.3389/ fimmu.2019.00318

252. Weksler ME. Changes in the B-cell Repertoire With Age. Vaccine (2000) 18 (16):1624-8. doi: 10.1016/S0264-410X(99)00497-1

253. Ahmed R, Omidian Z, Donner T, Hamad ARA. Hiding in Plain Sight: Time to Unlock Autoimmune Clues in Human CD5+ B Cells by Using Nextgen Technology. Discov Med (2018) 26(142):79-83.

254. Jergovic M, Contreras NA, Nikolich-Zugich J. Impact of CMV Upon Immune Aging: Facts and Fiction. Med Microbiol Immunol (2019) 208(34):263-9. doi: 10.1007/s00430-019-00605-w

255. Marchi E, Lee LN, Klenerman P. Inflation vs. Exhaustion of Antiviral Cd8+ T-Cell Populations in Persistent Infections: Two Sides of the Same Coin? Front Immunol (2019) 10:197. doi: 10.3389/fimmu.2019.00197

256. Wertheimer AM, Bennett MS, Park B, Uhrlaub JL, Martinez C, Pulko V, et al. Aging and Cytomegalovirus Infection Differentially and Jointly Affect Distinct Circulating T Cell Subsets in Humans. J Immunol (2014) 192 (5):2143-55. doi: 10.4049/jimmunol.1301721

257. Karrer U, Sierro S, Wagner M, Oxenius A, Hengel H, Koszinowski UH, et al. Memory Inflation: Continuous Accumulation of Antiviral CD8+ T Cells Over Time. J Immunol (2003) 170(4):2022-9. doi: 10.4049/jimmunol.170.4.2022

258. Sylwester AW, Mitchell BL, Edgar JB, Taormina C, Pelte C, Ruchti F, et al. Broadly Targeted Human Cytomegalovirus-Specific CD4+ and CD8+ T Cells Dominate the Memory Compartments of Exposed Subjects. J Exp Med (2005) 202(5):673-85. doi: 10.1084/jem.20050882

259. Pourgheysari B, Khan N, Best D, Bruton R, Nayak L, Moss PA. The Cytomegalovirus-Specific CD4+ T-Cell Response Expands With Age and Markedly Alters the CD4+ T-Cell Repertoire. J Virol (2007) 81(14):7759-65. doi: 10.1128/JVI.01262-06

260. Arens R, Wang P, Sidney J, Loewendorf A, Sette A, Schoenberger SP, et al. Cutting Edge: Murine Cytomegalovirus Induces a Polyfunctional CD4 T Cell Response. J Immunol (2008) 180(10):6472-6. doi: 10.4049/jimmunol. 180.10 .6472
261. Strindhall J, Lofgren S, Framsth C, Matussek A, Bengner M, Ernerudh J, et al. CD4/CD8 Ratio $<1$ is Associated With Lymphocyte Subsets, CMV and Gender in 71-Year Old Individuals: 5-Year Follow-Up of the Swedish Hexa Immune Longitudinal Study. Exp Gerontol (2017) 95:82-7. doi: 10.1016/j.exger.2017.03.020

262. Alonso-Arias R, Moro-Garcia MA, Echeverria A, Solano-Jaurrieta JJ, SuarezGarcia FM, Lopez-Larrea C. Intensity of the Humoral Response to Cytomegalovirus is Associated With the Phenotypic and Functional Status of the Immune System (Vol 87, Pg 4486, 2013). J Virol (2013) 87(15):8816-6. doi: $10.1128 /$ JVI.01378-13

263. Sansoni P, Vescovini R, Fagnoni FF, Akbar A, Arens R, Chiu YL, et al. New Advances in CMV and Immunosenescence. Exp Gerontol (2014) 55:54-62. doi: 10.1016/j.exger.2014.03.020

264. Bryl E, Vallejo AN, Weyand CM, Goronzy JJ. Down-Regulation of CD28 Expression by TNF-Alpha. J Immunol (2001) 167(6):3231-8. doi: 10.4049/ jimmunol.167.6.3231

265. Bartlett DB, Firth CM, Phillips AC, Moss P, Baylis D, Syddall H, et al. The Age-Related Increase in Low-Grade Systemic Inflammation (Inflammaging) is Not Driven by Cytomegalovirus Infection. Aging Cell (2012) 11(5):912-5. doi: 10.1111/j.1474-9726.2012.00849.x

266. Bennett JM, Glaser R, Malarkey WB, Beversdorf DQ, Peng J, Kiecolt-Glaser JK. Inflammation and Reactivation of Latent Herpesviruses in Older Adults. Brain Behav Immun (2012) 26(5):739-46. doi: 10.1016/j.bbi.2011.11.007

267. Frasca D, Blomberg BB. Aging, Cytomegalovirus (CMV) and Influenza Vaccine Responses. Hum Vaccin Immunother (2016) 12(3):682-90. doi: $10.1080 / 21645515.2015 .1105413$

268. Bowyer G, Sharpe H, Venkatraman N, Ndiaye PB, Wade D, Brenner N, et al. Reduced Ebola Vaccine Responses in CMV+ Young Adults is Associated With Expansion of CD57+KLRG1+ T Cells. J Exp Med (2020) 217(7): e20200004. doi: 10.1084/jem.20200004

269. Trzonkowski P, Mysliwska J, Szmit E, Wieckiewicz J, Lukaszuk K, Brydak LB, et al. Association Between Cytomegalovirus Infection, Enhanced Proinflammatory Response and Low Level of Anti-Hemagglutinins During the Anti-Influenza Vaccination-an Impact of Immunosenescence. Vaccine (2003) 21(25-26):3826-36. doi: 10.1016/S0264-410X(03)00309-8

270. Clement M, Marsden M, Stacey MA, Abdul-Karim J, Gimeno Brias S, Costa Bento D, et al. Cytomegalovirus-Specific IL-10-Producing Cd4+ T Cells Are Governed by Type-I Ifn-Induced IL-27 and Promote Virus Persistence. PLoS Pathog (2016) 12(12):e1006050. doi: 10.1371/journal.ppat.1006050

271. Merani S, Kuchel GA, Kleppinger A, McElhaney JE. Influenza VaccineMediated Protection in Older Adults: Impact of Influenza Infection, Cytomegalovirus Serostatus and Vaccine Dosage. Exp Gerontol (2018) 107:116-25. doi: 10.1016/j.exger.2017.09.015

272. van den Berg SPH, Wong A, Hendriks M, Jacobi RHJ, van Baarle D, van Beek J. Negative Effect of Age, But Not of Latent Cytomegalovirus Infection on the Antibody Response to a Novel Influenza Vaccine Strain in Healthy Adults. Front Immunol (2018) 9:82. doi: 10.3389/fimmu.2018.00082

273. Enani S, Przemska-Kosicka A, Childs CE, Maidens C, Dong H, Conterno L, et al. Impact of Ageing and a Synbiotic on the Immune Response to Seasonal Influenza Vaccination; a Randomised Controlled Trial. Clin Nutr (2018) 37 (2):443-51. doi: 10.1016/j.clnu.2017.01.011

274. Savva GM, Pachnio A, Kaul B, Morgan K, Huppert FA, Brayne C, et al. Cytomegalovirus Infection is Associated With Increased Mortality in the Older Population. Aging Cell (2013) 12(3):381-7. doi: 10.1111/acel.12059

275. van den Berg SPH, Warmink K, Borghans JAM, Knol MJ, van Baarle D. Effect of Latent Cytomegalovirus Infection on the Antibody Response to Influenza Vaccination: A Systematic Review and Meta-Analysis. Med Microbiol Immunol (2019) 208(3-4):305-21. doi: 10.1007/s00430-01900602-z

276. Furman D, Jojic V, Sharma S, Shen-Orr SS, Angel CJ, Onengut-Gumuscu S, et al. Cytomegalovirus Infection Enhances the Immune Response to Influenza. Sci Transl Med (2015) 7(281):281ra43. doi: 10.1126/scitranslmed.aaa2293

277. Bharucha T, Houlihan CF, Breuer J. Herpesvirus Infections of the Central Nervous System. Semin Neurol (2019) 39(3):369-82. doi: 10.1055/s-00391687837

278. Cocchio S, Gallo T, Baldo V. Herpes Zoster: Vaccination Status and Virtuous Experiences. Minerva Med (2020) 111(1):4-8. doi: 10.23736/S00264806.19.06412-7 
279. Shah RA, Limmer AL, Nwannunu CE, Patel RR, Mui UN, Tyring SK. Shingrix for Herpes Zoster: A Review. Skin Ther Lett (2019) 24(4):5-7.

280. Johnson RW, Levin MJ. Herpes Zoster and Its Prevention by Vaccination. Interdiscip Top Gerontol Geriatr (2020) 43:131-45. doi: 10.1159/000504484

281. Levin MJ, Cai GY, Manchak MD, Pizer LI. Varicella-Zoster Virus DNA in Cells Isolated From Human Trigeminal Ganglia. J Virol (2003) 77(12):697987. doi: 10.1128/JVI.77.12.6979-6987.2003

282. Ouwendijk WJD, Depledge DP, Rajbhandari L, Lenac Rovis T, Jonjic S, Breuer J, et al. Varicella-Zoster Virus VLT-ORF63 Fusion Transcript Induces Broad Viral Gene Expression During Reactivation From Neuronal Latency. Nat Commun (2020) 11(1):6324. doi: 10.1038/s41467-020-20031-4

283. Amanna IJ, Carlson NE, Slifka MK. Duration of Humoral Immunity to Common Viral and Vaccine Antigens. N Engl J Med (2007) 357(19):1903-15. doi: 10.1056/NEJMoa066092

284. Weinberg A, Zhang JH, Oxman MN, Johnson GR, Hayward AR, Caulfield MJ, et al. Varicella-Zoster Virus-Specific Immune Responses to Herpes Zoster in Elderly Participants in a Trial of a Clinically Effective Zoster Vaccine. J Infect Dis (2009) 200(7):1068-77. doi: 10.1086/605611

285. Steain M, Sutherland JP, Rodriguez M, Cunningham AL, Slobedman B, Abendroth A. Analysis of T Cell Responses During Active Varicella-Zoster Virus Reactivation in Human Ganglia. J Virol (2014) 88(5):2704-16. doi: 10.1128/JVI.03445-13

286. Kennedy PGE, Gershon AA. Clinical Features of Varicella-Zoster Virus Infection. Viruses (2018) 10(11):609. doi: 10.3390/v10110609

287. Gnann JWJr. Varicella-Zoster Virus: Atypical Presentations and Unusual Complications. J Infect Dis (2002) 186 Suppl 1:S91-8. doi: 10.1086/342963

288. Arvin AM. Human Herpesviruses: Biology, Therapy, and Immunoprophylaxis Vol. 1388. Cambridge, New York: Cambridge University Press (2007). doi: 10.1017/СBO9780511545313

289. Lachiewicz AM, Srinivas ML. Varicella-Zoster Virus Post-Exposure Management and Prophylaxis: A Review. Prev Med Rep (2019) 16:101016. doi: 10.1016/j.pmedr.2019.101016

290. Levin MJ. Immune Senescence and Vaccines to Prevent Herpes Zoster in Older Persons. Curr Opin Immunol (2012) 24(4):494-500. doi: 10.1016/ j.coi.2012.06.002

291. Takahashi M, Otsuka T, Okuno Y, Asano Y, Yazaki T. Live Vaccine Used to Prevent the Spread of Varicella in Children in Hospital. Lancet (1974) 2 (7892):1288-90. doi: 10.1016/S0140-6736(74)90144-5

292. Shaw J, Gershon AA. Varicella Virus Vaccination in the United States. Viral Immunol (2018) 31(2):96-103. doi: 10.1089/vim.2017.0136

293. Woodward M, Marko A, Galea S, Eagel B, Straus W. Varicella Virus Vaccine Live: A 22-Year Review of Postmarketing Safety Data. Open Forum Infect Dis (2019) 6(8):ofz295. doi: 10.1093/ofid/ofz295

294. Alexander KE, Tong PL, Macartney K, Beresford R, Sheppeard V, Gupta M. Live Zoster Vaccination in an Immunocompromised Patient Leading to Death Secondary to Disseminated Varicella Zoster Virus Infection. Vaccine (2018) 36(27):3890-3. doi: 10.1016/j.vaccine.2018.05.078

295. Levin MJ, Weinberg A. Immune Responses to Zoster Vaccines. Hum Vaccin Immunother (2019) 15(4):772-7. doi: 10.1080/21645515.2018.1560918

296. Blom K, Yin L, Arnheim-Dahlstrom L. Effectiveness of the Herpes Zoster Vaccine Zostavax(R) in Stockholm County, Sweden. Vaccine (2019) 37 (31):4401-6. doi: 10.1016/j.vaccine.2019.06.008

297. Dooling KL, Guo A, Patel M, Lee GM, Moore K, Belongia EA, et al. Recommendations of the Advisory Committee on Immunization Practices for Use of Herpes Zoster Vaccines. MMWR Morb Mortal Wkly Rep (2018) 67(3):103-8. doi: 10.15585/mmwr.mm6703a5

298. Winston DJ, Mullane KM, Cornely OA, Boeckh MJ, Brown JW, Pergam SA, et al. Inactivated Varicella Zoster Vaccine in Autologous Haemopoietic Stem-Cell Transplant Recipients: An International, Multicentre, Randomised, Double-Blind, Placebo-Controlled Trial. Lancet (2018) 391 (10135):2116-27. doi: 10.1016/S0140-6736(18)30631-7

299. Mullane KM, Morrison VA, Camacho LH, Arvin A, McNeil SA, Durrand J, et al. Safety and Efficacy of Inactivated Varicella Zoster Virus Vaccine in Immunocompromised Patients With Malignancies: A Two-Arm, Randomised, Double-Blind, Phase 3 Trial. Lancet Infect Dis (2019) 19 (9):1001-12. doi: 10.1016/S1473-3099(19)30310-X

300. Arnold N, Messaoudi I. Herpes Zoster and the Search for an Effective Vaccine. Clin Exp Immunol (2017) 187(1):82-92. doi: 10.1111/cei.12809
301. Heineman TC, Cunningham A, Levin M. Understanding the Immunology of Shingrix, a Recombinant Glycoprotein E Adjuvanted Herpes Zoster Vaccine. Curr Opin Immunol (2019) 59:42-8. doi: 10.1016/j.coi.2019.02.009

302. Levin MJ, Weinberg A. Adjuvanted Recombinant Glycoprotein E Herpes Zoster Vaccine. Clin Infect Dis (2019) 70(7):1509-15. doi: 10.1093/cid/ciz770

303. Short MD, Fergus C. Which Patients Should Receive the Herpes Zoster Vaccine? JAAPA (2019) 32(9):18-20. doi: 10.1097/01.JAA.0000578788.69674.2b

304. Chlibek R, Pauksens K, Rombo L, van Rijckevorsel G, Richardus JH, Plassmann G, et al. Long-Term Immunogenicity and Safety of an Investigational Herpes Zoster Subunit Vaccine in Older Adults. Vaccine (2016) 34(6):863-8. doi: 10.1016/j.vaccine.2015.09.073

305. Leroux-Roels G, Marchant A, Levy J, Van Damme P, Schwarz TF, Horsmans $\mathrm{Y}$, et al. Impact of Adjuvants on CD4(+) T Cell and B Cell Responses to a Protein Antigen Vaccine: Results From a Phase II, Randomized, Multicenter Trial. Clin Immunol (2016) 169:16-27. doi: 10.1016/j.clim.2016.05.007

306. Weinberg A, Popmihajlov Z, Schmader KE, Johnson MJ, Caldas Y, Salazar AT, et al. Persistence of Varicella-Zoster Virus Cell-Mediated Immunity After the Administration of a Second Dose of Live Herpes Zoster Vaccine. J Infect Dis (2019) 219(2):335-8. doi: 10.1093/infdis/jiy514

307. Schmader KE, Oxman MN, Levin MJ, Johnson G, Zhang JH, Betts R, et al. Persistence of the Efficacy of Zoster Vaccine in the Shingles Prevention Study and the Short-Term Persistence Substudy. Clin Infect Dis (2012) 55 (10):1320-8. doi: $10.1093 / \mathrm{cid} / \mathrm{cis} 638$

308. Sullivan NL, Eberhardt CS, Wieland A, Vora KA, Pulendran B, Ahmed R. Understanding the Immunology of the Zostavax Shingles Vaccine. Curr Opin Immunol (2019) 59:25-30. doi: 10.1016/j.coi.2019.02.005

309. Levin MJ, Bresnitz E, Popmihajlov Z, Weinberg A, Liaw KL, Willis E, et al. Studies With Herpes Zoster Vaccines in Immune Compromised Patients. Expert Rev Vaccines (2017) 16(12):1217-30. doi: 10.1080/14760584.2017.1395703

310. Tseng HF, Tartof S, Harpaz R, Luo Y, Sy LS, Hetcher RC, et al. Vaccination Against Zoster Remains Effective in Older Adults Who Later Undergo Chemotherapy. Clin Infect Dis (2014) 59(7):913-9. doi: 10.1093/cid/ciu498

311. Hoffmann M, Kleine-Weber H, Schroeder S, Kruger N, Herrler T, Erichsen S, et al. SARS-Cov-2 Cell Entry Depends on ACE2 and TMPRSS2 and Is Blocked by a Clinically Proven Protease Inhibitor. Cell (2020) 181(2):271-80. doi: 10.1016/j.cell.2020.02.052

312. Richardson S, Hirsch JS, Narasimhan M, Crawford JM, McGinn T, Davidson KW, et al. Presenting Characteristics, Comorbidities, and Outcomes Among 5700 Patients Hospitalized With Covid-19 in the New York City Area. JAMA (2020) 323(20):2052-9. doi: 10.1001/jama.2020.6775

313. Goyal P, Choi JJ, Pinheiro LC, Schenck EJ, Chen R, Jabri A, et al. Clinical Characteristics of Covid-19 in New York City. N Engl J Med (2020) 382 (24):2372-4. doi: 10.1056/NEJMc2010419

314. Wang D, Hu B, Hu C, Zhu F, Liu X, Zhang J, et al. Clinical Characteristics of 138 Hospitalized Patients With 2019 Novel Coronavirus-Infected Pneumonia in Wuhan, China. JAMA (2020) 323(11):1061-9. doi: 10.1001/jama.2020.1585

315. Petersen E, Koopmans M, Go U, Hamer DH, Petrosillo N, Castelli F, et al. Comparing SARS-CoV-2 With SARS-CoV and Influenza Pandemics. Lancet Infect Dis (2020) 20(9):e238-44. doi: 10.1016/S1473-3099(20)30484-9

316. Nichol KL, Nordin JD, Nelson DB, Mullooly JP, Hak E. Effectiveness of Influenza Vaccine in the Community-Dwelling Elderly. N Engl J Med (2007) 357(14):1373-81. doi: 10.1056/NEJMoa070844

317. Nassar MS, Bakhrebah MA, Meo SA, Alsuabeyl MS, Zaher WA. Middle East Respiratory Syndrome Coronavirus (Mers-CoV) Infection: Epidemiology, Pathogenesis and Clinical Characteristics. Eur Rev Med Pharmacol Sci (2018) 22(15):4956-61. doi: 10.26355/eurrev_201808_15635

318. Donnelly CA, Ghani AC, Leung GM, Hedley AJ, Fraser C, Riley S, et al. Epidemiological Determinants of Spread of Causal Agent of Severe Acute Respiratory Syndrome in Hong Kong. Lancet (2003) 361(9371):1761-6. doi: 10.1016/S0140-6736(03)13410-1

319. Meftahi GH, Jangravi Z, Sahraei H, Bahari Z. The Possible Pathophysiology Mechanism of Cytokine Storm in Elderly Adults With COVID-19 Infection: The Contribution of "Inflame-Aging". Inflamm Res (2020) 69(9):825-39. doi: 10.1007/s00011-020-01372-8

320. Rydyznski Moderbacher C, Ramirez SI, Dan JM, Grifoni A, Hastie KM, Weiskopf D, et al. Antigen-Specific Adaptive Immunity to SARS-CoV-2 in Acute Covid-19 and Associations With Age and Disease Severity. Cell (2020) 183(4):996-1012.e19. doi: 10.1016/j.cell.2020.09.038 
321. Moore JB, June CH. Cytokine Release Syndrome in Severe COVID-19. Science (2020) 368(6490):473-4. doi: 10.1126/science.abb8925

322. de la Rica R, Borges M, Gonzalez-Freire M. Covid-19: In the Eye of the Cytokine Storm. Front Immunol (2020) 11:558898. doi: 10.3389/ fimmu. 2020.558898

323. Takahashi T, Ellingson MK, Wong P, Israelow B, Lucas C, Klein J, et al. Sex Differences in Immune Responses That Underlie COVID-19 Disease Outcomes. Nature (2020) 588(7837):315-20. doi: 10.1038/s41586-020-2700-3

324. Tay MZ, Poh CM, Renia L, MacAry PA, Ng LFP. The Trinity of COVID-19: Immunity, Inflammation and Intervention. Nat Rev Immunol (2020) 20 (6):363-74. doi: 10.1038/s41577-020-0311-8

325. Pietrobon AJ, Teixeira FME, Sato MN. I Mmunosenescence and Inflammaging: Risk Factors of Severe Covid-19 in Older People. Front Immunol (2020) 11:579220. doi: 10.3389/fimmu.2020.579220

326. Lan J, Ge J, Yu J, Shan S, Zhou H, Fan S, et al. Structure of the SARS-CoV-2 Spike Receptor-Binding Domain Bound to the ACE2 Receptor. Nature (2020) 581(7807):215-20. doi: 10.1038/s41586-020-2180-5

327. Vaduganathan M, Vardeny O, Michel T, McMurray JJV, Pfeffer MA, Solomon SD. Renin-Angiotensin-Aldosterone System Inhibitors in Patients With Covid-19. N Engl J Med (2020) 382(17):1653-9. doi: 10.1056/NEJMsr2005760

328. McElhaney JE, Verschoor CP, Andrew MK, Haynes L, Kuchel GA, Pawelec G. The Immune Response to Influenza in Older Humans: Beyond Immune Senescence. Immun Ageing (2020) 17:10. doi: 10.1186/s12979-020-00181-1

329. Clegg A, Young J, Iliffe S, Rikkert MO, Rockwood K. Frailty in Elderly People. Lancet (2013) 381(9868):752-62. doi: 10.1016/S0140-6736(12)62167-9

330. Louie JK, Acosta M, Winter K, Jean C, Gavali S, Schechter R, et al. Factors Associated With Death or Hospitalization Due to Pandemic 2009 Influenza A(H1N1) Infection in California. JAMA (2009) 302(17):1896-902. doi: 10.1001/jama.2009.1583

331. Kwong JC, Campitelli MA, Gubbay JB, Peci A, Winter AL, Olsha R, et al. Vaccine Effectiveness Against Laboratory-Confirmed Influenza Hospitalizations Among Elderly Adults During the 2010-2011 Season. Clin Infect Dis (2013) 57(6):820-7. doi: 10.1093/cid/cit404

332. Dawood FS, Chung JR, Kim SS, Zimmerman RK, Nowalk MP, Jackson ML, et al. Interim Estimates of 2019-20 Seasonal Influenza Vaccine Effectiveness United States, February 2020. MMWR Morb Mortal Wkly Rep (2020) 69 (7):177-82. doi: 10.15585/mmwr.mm6907a1

333. Ward BJ, Pillet S, Charland N, Trepanier S, Couillard J, Landry N. The Establishment of Surrogates and Correlates of Protection: Useful Tools for the Licensure of Effective Influenza Vaccines? Hum Vaccin Immunother (2018) 14(3):647-56. doi: 10.1080/21645515.2017.1413518

334. Carlock MA, Ingram JG, Clutter EF, Cecil NC, Ramgopal M, Zimmerman RK, et al. Impact of Age and Pre-Existing Immunity on the Induction of Human Antibody Responses Against Influenza B Viruses. Hum Vaccin Immunother (2019) 15(9):2030-43. doi: 10.1080/21645515.2019.1642056

335. Goodwin K, Viboud C, Simonsen L. Antibody Response to Influenza Vaccination in the Elderly: A Quantitative Review. Vaccine (2006) 24 (8):1159-69. doi: 10.1016/j.vaccine.2005.08.105

336. Sasaki S, Sullivan M, Narvaez CF, Holmes TH, Furman D, Zheng NY, et al. Limited Efficacy of Inactivated Influenza Vaccine in Elderly Individuals is Associated With Decreased Production of Vaccine-Specific Antibodies. J Clin Invest (2011) 121(8):3109-19. doi: 10.1172/JCI57834

337. Ju CH, Blum LK, Kongpachith S, Lingampalli N, Mao R, Brodin P, et al. Plasmablast Antibody Repertoires in Elderly Influenza Vaccine Responders Exhibit Restricted Diversity But Increased Breadth of Binding Across Influenza Strains. Clin Immunol (2018) 193:70-9. doi: 10.1016/j.clim.2018.01.011

338. Henry C, Zheng NY, Huang M, Cabanov A, Rojas KT, Kaur K, et al. Influenza Virus Vaccination Elicits Poorly Adapted B Cell Responses in Elderly Individuals. Cell Host Microbe (2019) 25(3):357-66.e6. doi: 10.1016/ j.chom.2019.01.002

339. Dugan HL, Guthmiller JJ, Arevalo P, Huang M, Chen YQ, Neu KE, et al. Preexisting Immunity Shapes Distinct Antibody Landscapes After Influenza Virus Infection and Vaccination in Humans. Sci Transl Med (2020) 12(573): eabd3601. doi: 10.1126/scitranslmed.abd3601

340. Fonville JM, Wilks SH, James SL, Fox A, Ventresca M, Aban M, et al. Antibody Landscapes After Influenza Virus Infection or Vaccination. Science (2014) 346(6212):996-1000. doi: 10.1126/science.1256427
341. Sridhar S, Begom S, Bermingham A, Hoschler K, Adamson W, Carman W, et al. Cellular Immune Correlates of Protection Against Symptomatic Pandemic Influenza. Nat Med (2013) 19(10):1305-12. doi: 10.1038/nm.3350

342. Wilkinson TM, Li CK, Chui CS, Huang AK, Perkins M, Liebner JC, et al. Preexisting Influenza-Specific CD4+ T Cells Correlate With Disease Protection Against Influenza Challenge in Humans. Nat Med (2012) 18 (2):274-80. doi: $10.1038 / \mathrm{nm} .2612$

343. Koutsakos M, Illing PT, Nguyen THO, Mifsud NA, Crawford JC, Rizzetto S, et al. Human Cd8(+) T Cell Cross-Reactivity Across Influenza a, B and C Viruses. Nat Immunol (2019) 20(5):613-25. doi: 10.1038/s41590-019-0320-6

344. Altenburg AF, Rimmelzwaan GF, de Vries RD. Virus-Specific T Cells as Correlate of (Cross-)Protective Immunity Against Influenza. Vaccine (2015) 33(4):500-6. doi: 10.1016/j.vaccine.2014.11.054

345. Nguyen THO, Sant S, Bird NL, Grant EJ, Clemens EB, Koutsakos M, et al. Perturbed Cd8(+) T Cell Immunity Across Universal Influenza Epitopes in the Elderly. J Leukoc Biol (2018) 103(2):321-39. doi: 10.1189/jlb.5MA0517207R

346. Park HJ, Shin MS, Kim M, Bilsborrow JB, Mohanty S, Montgomery RR, et al. Transcriptomic Analysis of Human IL-7 Receptor Alpha (Low) and (High) Effector Memory CD8(+) T Cells Reveals an Age-Associated Signature Linked to Influenza Vaccine Response in Older Adults. Aging Cell (2019) 18(4):e12960. doi: 10.1111/acel.12960

347. Eaton SM, Burns EM, Kusser K, Randall TD, Haynes L. Age-Related Defects in CD4 T Cell Cognate Helper Function Lead to Reductions in Humoral Responses. J Exp Med (2004) 200(12):1613-22. doi: 10.1084/jem.20041395

348. Herati RS, Reuter MA, Dolfi DV, Mansfield KD, Aung H, Badwan OZ, et al. Circulating CXCR5+PD-1+ Response Predicts Influenza Vaccine Antibody Responses in Young Adults But Not Elderly Adults. J Immunol (2014) 193 (7):3528-37. doi: 10.4049/jimmunol.1302503

349. Lefebvre JS, Masters AR, Hopkins JW, Haynes L. Age-Related Impairment of Humoral Response to Influenza is Associated With Changes in Antigen Specific T Follicular Helper Cell Responses. Sci Rep (2016) 6:25051. doi: $10.1038 /$ srep25051

350. Richards KA, Shannon I, Treanor JJ, Yang H, Nayak JL, Sant AJ. Evidence That Blunted CD4 T-Cell Responses Underlie Deficient Protective Antibody Responses to Influenza Vaccines in Repeatedly Vaccinated Human Subjects. J Infect Dis (2020) 222(2):273-7. doi: 10.1093/infdis/jiz433

351. Cowling BJ, Perera R, Valkenburg SA, Leung NHL, Iuliano AD, Tam YH, et al. Comparative Immunogenicity of Several Enhanced Influenza Vaccine Options for Older Adults: A Randomized, Controlled Trial. Clin Infect Dis (2020) 71(7):1704-14. doi: 10.1093/cid/ciz1034

352. Hart RJ. An Outbreak of Respiratory Syncytial Virus Infection in an Old People's Home. J Infect (1984) 8(3):259-61. doi: 10.1016/S0163-4453(84)94075-1

353. Sorvillo FJ, Huie SF, Strassburg MA, Butsumyo A, Shandera WX, Fannin SL. An Outbreak of Respiratory Syncytial Virus Pneumonia in a Nursing Home for the Elderly. J Infect (1984) 9(3):252-6. doi: 10.1016/S0163-4453(84)90530-9

354. Branche AR, Falsey AR. Respiratory Syncytial Virus Infection in Older Adults: An Under-Recognized Problem. Drugs Aging (2015) 32(4):261-9. doi: 10.1007/s40266-015-0258-9

355. Rossey I, Saelens X. Vaccines Against Human Respiratory Syncytial Virus in Clinical Trials, Where are We Now? Expert Rev Vaccines (2019) 18 (10):1053-67. doi: 10.1080/14760584.2019.1675520

356. Drysdale SB, Barr RS, Rollier CS, Green CA, Pollard AJ, Sande CJ. Priorities for Developing Respiratory Syncytial Virus Vaccines in Different Target Populations. Sci Transl Med (2020) 12(535):eaax2466. doi: 10.1126/ scitranslmed.aax2466

357. Swanson KA, Rainho-Tomko JN, Williams ZP, Lanza L, Peredelchuk M, Kishko M, et al. A Respiratory Syncytial Virus (RSV) F Protein Nanoparticle Vaccine Focuses Antibody Responses to a Conserved Neutralization Domain. Sci Immunol (2020) 5(47):eaba6466. doi: 10.1126/sciimmunol.aba6466

358. Capella C, Chaiwatpongsakorn S, Gorrell E, Risch ZA, Ye F, Mertz SE, et al. Prefusion F, and Disease Severity in Infants and Young Children With Acute Respiratory Syncytial Virus Infection. J Infect Dis (2017) 216(11):1398-406. doi: 10.1093/infdis/jix489

359. Blanco JCG, Pletneva LM, McGinnes-Cullen L, Otoa RO, Patel MC, Fernando LR, et al. Efficacy of a Respiratory Syncytial Virus Vaccine Candidate in a Maternal Immunization Model. Nat Commun (2018) 9(1):1904. doi: 10.1038/ s41467-018-04216-6 
360. Palomo C, Mas V, Thom M, Vazquez M, Cano O, Terron MC, et al. Influence of Respiratory Syncytial Virus F Glycoprotein Conformation on Induction of Protective Immune Responses. J Virol (2016) 90(11):5485-98. doi: 10.1128/JVI.00338-16

361. Falsey AR, Walsh EE. Relationship of Serum Antibody to Risk of Respiratory Syncytial Virus Infection in Elderly Adults. J Infect Dis (1998) 177(2):463-6. doi: 10.1086/517376

362. Bagga B, Cehelsky JE, Vaishnaw A, Wilkinson T, Meyers R, Harrison LM, et al. Effect of Preexisting Serum and Mucosal Antibody on Experimental Respiratory Syncytial Virus (Rsv) Challenge and Infection of Adults. J Infect Dis (2015) 212(11):1719-25. doi: 10.1093/infdis/jiv281

363. Walsh EE, Peterson DR, Falsey AR. Risk Factors for Severe Respiratory Syncytial Virus Infection in Elderly Persons. J Infect Dis (2004) 189(2):233-8. doi: $10.1086 / 380907$

364. de Bree GJ, Heidema J, van Leeuwen EM, van Bleek GM, Jonkers RE, Jansen HM, et al. Respiratory Syncytial Virus-Specific CD8+ Memory T Cell Responses in Elderly Persons. J Infect Dis (2005) 191(10):1710-8. doi: 10.1086/429695

365. Cusi MG, Martorelli B, Di Genova G, Terrosi C, Campoccia G, Correale P. Age Related Changes in T Cell Mediated Immune Response and Effector Memory to Respiratory Syncytial Virus (RSV) in Healthy Subjects. Immun Ageing (2010) 7:14. doi: 10.1186/1742-4933-7-14

366. Cherukuri A, Patton K, Gasser RAJr., Zuo F, Woo J, Esser MT, et al. Adults 65 Years Old and Older Have Reduced Numbers of Functional Memory T Cells to Respiratory Syncytial Virus Fusion Protein. Clin Vaccine Immunol (2013) 20(2):239-47. doi: 10.1128/CVI.00580-12

367. Hall CB, Walsh EE, Long CE, Schnabel KC. Immunity to and Frequency of Reinfection With Respiratory Syncytial Virus. J Infect Dis (1991) 163(4):6938. doi: 10.1093/infdis/163.4.693

368. Jozwik A, Habibi MS, Paras A, Zhu J, Guvenel A, Dhariwal J, et al. RSVSpecific Airway Resident Memory CD8+ T Cells and Differential Disease Severity After Experimental Human Infection. Nat Commun (2015) 6:10224. doi: 10.1038/ncomms10224

369. Katz PS, Siggins RW, Porretta C, Armstrong ML, Zea AH, Mercante DE, et al. Chronic Alcohol Increases CD8+ T-Cell Immunosenescence in Simian Immunodeficiency Virus-Infected Rhesus Macaques. Alcohol (2015) 49 (8):759-65. doi: 10.1016/j.alcohol.2015.09.003

370. Cho SY, Kim J, Lee JH, Sim JH, Cho DH, Bae IH, et al. Modulation of Gut Microbiota and Delayed Immunosenescence as a Result of Syringaresinol Consumption in Middle-Aged Mice. Sci Rep (2016) 6:39026. doi: 10.1038/ srep39026

371. Turner JE, Brum PC. Does Regular Exercise Counter T Cell Immunosenescence Reducing the Risk of Developing Cancer and Promoting Successful Treatment of Malignancies? Oxid Med Cell Longev (2017) 2017:4234765. doi: 10.1155/2017/ 4234765

372. Turner JE. Is Immunosenescence Influenced by Our Lifetime "Dose" of Exercise? Biogerontology (2016) 17(3):581-602. doi: 10.1007/s10522-0169642-z

373. Choi IY, Lee C, Longo VD. Nutrition and Fasting Mimicking Diets in the Prevention and Treatment of Autoimmune Diseases and Immunosenescence. Mol Cell Endocrinol (2017) 455:4-12. doi: 10.1016/j.mce.2017.01.042

374. Ripa M, Chiappetta S, Tambussi G. Immunosenescence and Hurdles in the Clinical Management of Older HIV-Patients. Virulence (2017) 8(5):508-28. doi: 10.1080/21505594.2017.1292197

375. Partridge L, Deelen J, Slagboom PE. Facing Up to the Global Challenges of Ageing. Nature (2018) 561(7721):45-56. doi: 10.1038/s41586-018-0457-8

376. Scola L, Candore G, Colonna-Romano G, Crivello A, Forte GI, Paolisso G, et al. Study of the Association With -330T/G IL-2 in a Population of Centenarians From Centre and South Italy. Biogerontology (2005) 6(6):425-9. doi: 10.1007/ s10522-005-4909-9

377. Capri M, Monti D, Salvioli S, Lescai F, Pierini M, Altilia S, et al. Complexity of Anti-Immunosenescence Strategies in Humans. Artif Organs (2006) 30 (10):730-42. doi: 10.1111/j.1525-1594.2006.00295.x

378. Laupeze B, van der Most R, Del Giudice G. Novel Technologies to Improve Vaccines for Older Adults. Interdiscip Top Gerontol Geriatr (2020) 43:21833. doi: $10.1159 / 000504485$

379. Partridge L, Fuentealba M, Kennedy BK. The Quest to Slow Ageing Through Drug Discovery. Nat Rev Drug Discovery (2020) 19(8):513-32. doi: 10.1038/ s41573-020-0067-7
380. Jun JI, Lau LF. The Matricellular Protein CCN1 Induces Fibroblast Senescence and Restricts Fibrosis in Cutaneous Wound Healing. Nat Cell Biol (2010) 12(7):676-85. doi: 10.1038/ncb2070

381. Krizhanovsky V, Yon M, Dickins RA, Hearn S, Simon J, Miething C, et al. Senescence of Activated Stellate Cells Limits Liver Fibrosis. Cell (2008) 134 (4):657-67. doi: 10.1016/j.cell.2008.06.049

382. Munoz-Espin D, Canamero M, Maraver A, Gomez-Lopez G, Contreras J, MurilloCuesta S, et al. Programmed Cell Senescence During Mammalian Embryonic Development. Cell (2013) 155(5):1104-18. doi: 10.1016/j.cell.2013.10.019

383. Kang TW, Yevsa T, Woller N, Hoenicke L, Wuestefeld T, Dauch D, et al. Senescence Surveillance of Pre-Malignant Hepatocytes Limits Liver Cancer Development. Nature (2011) 479(7374):547-51. doi: 10.1038/nature10599

384. Xue W, Zender L, Miething C, Dickins RA, Hernando E, Krizhanovsky V, et al. Senescence and Tumour Clearance is Triggered by p53 Restoration in Murine Liver Carcinomas. Nature (2007) 445(7128):656-60. doi: 10.1038/ nature 05529

385. Ovadya Y, Landsberger T, Leins H, Vadai E, Gal H, Biran A, et al. Impaired Immune Surveillance Accelerates Accumulation of Senescent Cells and Aging. Nat Commun (2018) 9(1):5435. doi: 10.1038/s41467-018-07825-3

386. Childs BG, Durik M, Baker DJ, van Deursen JM. Cellular Senescence in Aging and Age-Related Disease: From Mechanisms to Therapy. Nat Med (2015) 21(12):1424-35. doi: 10.1038/nm.4000

387. Walters MS, De BP, Salit J, Buro-Auriemma LJ, Wilson T, Rogalski AM, et al. Smoking Accelerates Aging of the Small Airway Epithelium. Respir Res (2014) 15:94. doi: 10.1186/s12931-014-0094-1

388. Matthews C, Gorenne I, Scott S, Figg N, Kirkpatrick P, Ritchie A, et al. Vascular Smooth Muscle Cells Undergo Telomere-Based Senescence in Human Atherosclerosis: Effects of Telomerase and Oxidative Stress. Circ Res (2006) 99(2):156-64. doi: 10.1161/01.RES.0000233315.38086.bc

389. Cmielova J, Havelek R, Soukup T, Jiroutova A, Visek B, Suchanek J, et al. Gamma Radiation Induces Senescence in Human Adult Mesenchymal Stem Cells From Bone Marrow and Periodontal Ligaments. Int J Radiat Biol (2012) 88(5):393-404. doi: 10.3109/09553002.2012.666001

390. Kirkland JL, Tchkonia T. Senolytic Drugs: From Discovery to Translation. J Intern Med (2020) 288(5):518-36. doi: 10.1111/joim.13141

391. Baar MP, Brandt RMC, Putavet DA, Klein JDD, Derks KWJ, Bourgeois BRM, et al. Targeted Apoptosis of Senescent Cells Restores Tissue Homeostasis in Response to Chemotoxicity and Aging. Cell (2017) 169 (1):132-47.e16. doi: 10.1016/j.cell.2017.02.031

392. Singh R, Letai A, Sarosiek K. Regulation of Apoptosis in Health and Disease: The Balancing Act of BCL-2 Family Proteins. Nat Rev Mol Cell Biol (2019) 20 (3):175-93. doi: 10.1038/s41580-018-0089-8

393. Xu M, Pirtskhalava T, Farr JN, Weigand BM, Palmer AK, Weivoda MM, et al. Senolytics Improve Physical Function and Increase Lifespan in Old Age. Nat Med (2018) 24(8):1246-56. doi: 10.1038/s41591-018-0092-9

394. Yousefzadeh MJ, Zhu Y, McGowan SJ, Angelini L, Fuhrmann-Stroissnigg H, $\mathrm{Xu} \mathrm{M}$, et al. Fisetin is a Senotherapeutic That Extends Health and Lifespan. EBioMedicine (2018) 36:18-28. doi: 10.1016/j.ebiom.2018.09.015

395. Merkel O, Taylor N, Prutsch N, Staber PB, Moriggl R, Turner SD, et al. When the Guardian Sleeps: Reactivation of the p53 Pathway in Cancer. Mutat Res (2017) 773:1-13. doi: 10.1016/j.mrrev.2017.02.003

396. Wang AS, Dreesen O. Biomarkers of Cellular Senescence and Skin Aging. Front Genet (2018) 9:247. doi: 10.3389/fgene.2018.00247

397. Mizukoshi E, Kaneko S. Telomerase-Targeted Cancer Immunotherapy. Int $J$ Mol Sci (2019) 20(8):1823. doi: 10.3390/ijms20081823

398. Fuhrmann-Stroissnigg H, Niedernhofer LJ, Robbins PD. Hsp90 Inhibitors as Senolytic Drugs to Extend Healthy Aging. Cell Cycle (2018) 17(9):1048-55. doi: 10.1080/15384101.2018.1475828

399. Kuilman T, Michaloglou C, Vredeveld LC, Douma S, van Doorn R, Desmet $\mathrm{CJ}$, et al. Oncogene-Induced Senescence Relayed by an InterleukinDependent Inflammatory Network. Cell (2008) 133(6):1019-31. doi: 10.1016/j.cell.2008.03.039

400. Song S, Lam EW, Tchkonia T, Kirkland JL, Sun Y. Senescent Cells: Emerging Targets for Human Aging and Age-Related Diseases. Trends Biochem Sci (2020) 45(7):578-92. doi: 10.1016/j.tibs.2020.03.008

401. Prata L, Ovsyannikova IG, Tchkonia T, Kirkland JL. Senescent Cell Clearance by the Immune System: Emerging Therapeutic Opportunities. Semin Immunol (2018) 40:101275. doi: 10.1016/j.smim.2019.04.003 
402. Basisty N, Kale A, Jeon OH, Kuehnemann C, Payne T, Rao C, et al. A Proteomic Atlas of Senescence-Associated Secretomes for Aging Biomarker Development. PLoS Biol (2020) 18(1):e3000599. doi: 10.1371/journal.pbio.3000599

403. Lei Q, Liu T, Gao F, Xie H, Sun L, Zhao A, et al. Microvesicles as Potential Biomarkers for the Identification of Senescence in Human Mesenchymal Stem Cells. Theranostics (2017) 7(10):2673-89. doi: 10.7150/thno.18915

404. Terlecki-Zaniewicz L, Lammermann I, Latreille J, Bobbili MR, Pils V, Schosserer M, et al. Small Extracellular Vesicles and Their miRNA Cargo are AntiApoptotic Members of the Senescence-Associated Secretory Phenotype. Aging (Albany NY) (2018) 10(5):1103-32. doi: 10.18632/aging.101452

405. Takasugi M, Okada R, Takahashi A, Virya Chen D, Watanabe S, Hara E. Small Extracellular Vesicles Secreted From Senescent Cells Promote Cancer Cell Proliferation Through Epha2. Nat Commun (2017) 8:15729. doi: $10.1038 /$ ncomms 15728

406. Walters HE, Deneka-Hannemann S, Cox LS. Reversal of Phenotypes of Cellular Senescence by pan-mTOR Inhibition. Aging (Albany NY) (2016) 8 (2):231-44. doi: 10.18632/aging.100872

407. Mannick JB, Morris M, Hockey HP, Roma G, Beibel M, Kulmatycki K, et al. TORC1 Inhibition Enhances Immune Function and Reduces Infections in the Elderly. Sci Transl Med (2018) 10(449):eaaq1564. doi: 10.1126/ scitranslmed.aaq1564

408. Dumas SN, Lamming DW. Next Generation Strategies for Geroprotection Via mTORC1 Inhibition. J Gerontol A Biol Sci Med Sci (2020) 75(1):14-23. doi: 10.1093/gerona/glz056

409. Henson SM, Lanna A, Riddell NE, Franzese O, Macaulay R, Griffiths SJ, et al. p38 Signaling Inhibits mTORC1-independent Autophagy in Senescent Human CD8(+) T Cells. J Clin Invest (2014) 124(9):4004-16. doi: 10.1172/JCI75051

410. Zhang S, Kaplan MH. The p38 Mitogen-Activated Protein Kinase is Required for IL-12-induced IFN-Gamma Expression. J Immunol (2000) 165(3):1374-80. doi: 10.4049/jimmunol.165.3.1374

411. Alimbetov D, Davis T, Brook AJ, Cox LS, Faragher RG, Nurgozhin T, et al. Suppression of the Senescence-Associated Secretory Phenotype (SASP) in Human Fibroblasts Using Small Molecule Inhibitors of P38 MAP Kinase and MK2. Biogerontology (2016) 17(2):305-15. doi: 10.1007/s10522-015-9610-z

412. Freund A, Patil CK, Campisi J. p38MAPK is a Novel DNA Damage Response-Independent Regulator of the Senescence-Associated Secretory Phenotype. ЕMBO J (2011) 30(8):1536-48. doi: 10.1038/emboj.2011.69

413. Lanna A, Gomes DC, Muller-Durovic B, McDonnell T, Escors D, Gilroy DW, et al. A Sestrin-Dependent Erk-Jnk-p38 MAPK Activation Complex Inhibits Immunity During Aging. Nat Immunol (2017) 18(3):354-63. doi: 10.1038/ni.3665

414. Chung HY, Kim HJ, Kim JW, Yu BP. The Inflammation Hypothesis of Aging: Molecular Modulation by Calorie Restriction. Ann N Y Acad Sci (2001) 928:327-35. doi: 10.1111/j.1749-6632.2001.tb05662.x

415. Chung KW, Kim DH, Park MH, Choi YJ, Kim ND, Lee J, et al. Recent Advances in Calorie Restriction Research on Aging. Exp Gerontol (2013) 48 (10):1049-53. doi: 10.1016/j.exger.2012.11.007

416. Walters HE, Cox LS. Mtorc Inhibitors as Broad-Spectrum Therapeutics for Age-Related Diseases. Int J Mol Sci (2018) 19(8):2325. doi: 10.3390/ ijms 19082325

417. Barzilai N, Crandall JP, Kritchevsky SB, Espeland MA. Metformin as a Tool to Target Aging. Cell Metab (2016) 23(6):1060-5. doi: 10.1016/j.cmet.2016.05.011

418. Ansaldi F, Bacilieri S, Durando P, Sticchi L, Valle L, Montomoli E, et al. Cross-Protection by MF59-adjuvanted Influenza Vaccine: Neutralizing and Haemagglutination-Inhibiting Antibody Activity Against A(H3N2) Drifted Influenza Viruses. Vaccine (2008) 26(12):1525-9. doi: 10.1016/j.vaccine. 2008.01.019

419. Beran J, Reynales H, Poder A, Yu CY, Pitisuttithum P, Yuan LL, et al. Prevention of Influenza During Mismatched Seasons in Older Adults With an MF59-adjuvanted Quadrivalent Influenza Vaccine: A Randomised, Controlled, Multicentre, Phase 3 Efficacy Study. Lancet Infect Dis (2021) S1473-3099(20):30694-0. doi: 10.1016/S1473-3099(20)30694-0

420. Cioncada R, Maddaluno M, Vo HTM, Woodruff M, Tavarini S, Sammicheli C, et al. Vaccine Adjuvant MF59 Promotes the Intranodal Differentiation of Antigen-Loaded and Activated Monocyte-Derived Dendritic Cells. PLoS One (2017) 12(10):e0185843. doi: 10.1371/journal.pone.0185843

421. O'Hagan DT, Ott GS, De Gregorio E, Seubert A. The Mechanism of Action of MF59 - an Innately Attractive Adjuvant Formulation. Vaccine (2012) 30 (29):4341-8. doi: 10.1016/j.vaccine.2011.09.061
422. Nicholson KG, Abrams KR, Batham S, Clark TW, Hoschler K, Lim WS, et al. Immunogenicity and Safety of a Two-Dose Schedule of Whole-Virion and AS03A-adjuvanted 2009 Influenza A (H1N1) Vaccines: A Randomised, Multicentre, Age-Stratified, Head-to-Head Trial. Lancet Infect Dis (2011) 11(2):91-101. doi: 10.1016/S1473-3099(10)70296-6

423. Didierlaurent AM, Laupeze B, Di Pasquale A, Hergli N, Collignon C, Garcon N. Adjuvant System AS01: Helping to Overcome the Challenges of Modern Vaccines. Expert Rev Vaccines (2017) 16(1):55-63. doi: 10.1080/14760584. 2016.1213632

424. Lal H, Cunningham AL, Godeaux O, Chlibek R, Diez-Domingo J, Hwang SJ, et al. Efficacy of an Adjuvanted Herpes Zoster Subunit Vaccine in Older Adults. N Engl J Med (2015) 372(22):2087-96. doi: 10.1056/NEJMoa1501184

425. Weinberger B. Adjuvant Strategies to Improve Vaccination of the Elderly Population. Curr Opin Pharmacol (2018) 41:34-41. doi: 10.1016/j.coph.2018.03.014

426. Holland D, Booy R, De Looze F, Eizenberg P, McDonald J, Karrasch J, et al. Intradermal Influenza Vaccine Administered Using a New Microinjection System Produces Superior Immunogenicity in Elderly Adults: A Randomized Controlled Trial. J Infect Dis (2008) 198(5):650-8. doi: 10.1086/590434

427. DiazGranados CA, Dunning AJ, Kimmel M, Kirby D, Treanor J, Collins A, et al. Efficacy of High-Dose Versus Standard-Dose Influenza Vaccine in Older Adults. N Engl J Med (2014) 371(7):635-45. doi: 10.1056/NEJMoa1315727

428. Ng TWY, Cowling BJ, Gao HZ, Thompson MG. Comparative Immunogenicity of Enhanced Seasonal Influenza Vaccines in Older Adults: A Systematic Review and Meta-Analysis. J Infect Dis (2019) 219 (10):1525-35. doi: 10.1093/infdis/jiy720

429. Shinde V, Fries L, Wu Y, Agrawal S, Cho I, Thomas DN, et al. Improved Titers Against Influenza Drift Variants With a Nanoparticle Vaccine. N Engl J Med (2018) 378(24):2346-8. doi: 10.1056/NEJMc1803554

430. Anderson EJ, Rouphael NG, Widge AT, Jackson LA, Roberts PC, Makhene M, et al. Safety and Immunogenicity of SARS-CoV-2 Mrna-1273 Vaccine in Older Adults. N Engl J Med (2020) 383(25):2427-38. doi: 10.1056/NEJMoa2028436

431. Andrew MK, Shinde V, Ye L, Hatchette T, Haguinet F, Dos Santos G, et al. The Importance of Frailty in the Assessment of Influenza Vaccine Effectiveness Against Influenza-Related Hospitalization in Elderly People. J Infect Dis (2017) 216(4):405-14. doi: 10.1093/infdis/jix282

432. Netea MG, Dominguez-Andres J, Barreiro LB, Chavakis T, Divangahi M, Fuchs E, et al. Defining Trained Immunity and its Role in Health and Disease. Nat Rev Immunol (2020) 20(6):375-88. doi: 10.1038/s41577-020-0285-6

433. Netea MG, Joosten LA, Latz E, Mills KH, Natoli G, Stunnenberg HG, et al. Trained Immunity: A Program of Innate Immune Memory in Health and Disease. Science (2016) 352(6284):aaf1098. doi: 10.1126/science.aaf1098

434. Higgins JP, Soares-Weiser K, Lopez-Lopez JA, Kakourou A, Chaplin K, Christensen H, et al. Association of BCG, DTP, and Measles Containing Vaccines With Childhood Mortality: Systematic Review. BMJ (2016) 355: i5170. doi: 10.1136/bmj.i5170

435. Aaby P, Roth A, Ravn H, Napirna BM, Rodrigues A, Lisse IM, et al. Randomized Trial of BCG Vaccination At Birth to Low-Birth-Weight Children: Beneficial Nonspecific Effects in the Neonatal Period? J Infect Dis (2011) 204(2):245-52. doi: 10.1093/infdis/jir240

436. Ter Horst R, Jaeger M, Smeekens SP, Oosting M, Swertz MA, Li Y, et al. Host and Environmental Factors Influencing Individual Human Cytokine Responses. Cell (2016) 167(4):1111-24.e13. doi: 10.1016/j.cell.2016.10.018

437. Wardhana EA, Sultana A, Mandang VV, Jim E. The Efficacy of Bacillus Calmette-Guerin Vaccinations for the Prevention of Acute Upper Respiratory Tract Infection in the Elderly. Acta Med Indones (2011) 43(3):185-90.

438. Leentjens J, Kox M, Stokman R, Gerretsen J, Diavatopoulos DA, van Crevel R, et al. Bcg Vaccination Enhances the Immunogenicity of Subsequent Influenza Vaccination in Healthy Volunteers: A Randomized, Placebo-Controlled Pilot Study. J Infect Dis (2015) 212(12):1930-8. doi: 10.1093/infdis/jiv332

439. Bulut O, Kilic G, Dominguez-Andres J, Netea MG. Overcoming Immune Dysfunction in the Elderly: Trained Immunity as a Novel Approach. Int Immunol (2020) 32(12):741-53. doi: 10.1093/intimm/dxaa052

440. Gorgoulis V, Adams PD, Alimonti A, Bennett DC, Bischof O, Bishop C, et al. Cellular Senescence: Defining a Path Forward. Cell (2019) 179(4):813-27. doi: 10.1016/j.cell.2019.10.005

441. Baker DJ, Wijshake T, Tchkonia T, LeBrasseur NK, Childs BG, van de Sluis B, et al. Clearance of p16Ink4a-positive Senescent Cells Delays Ageing-Associated Disorders. Nature (2011) 479(7372):232-6. doi: 10.1038/nature10600 
442. Demaria M, Ohtani N, Youssef SA, Rodier F, Toussaint W, Mitchell JR, et al. An Essential Role for Senescent Cells in Optimal Wound Healing Through Secretion of PDGF-AA. Dev Cell (2014) 31(6):722-33. doi: 10.1016/j.devcel.2014.11.012

Conflict of Interest: The authors declare that the research was conducted in the absence of any commercial or financial relationships that could be construed as a potential conflict of interest.
Copyright (C) 2021 Palacios-Pedrero, Osterhaus, Becker, Elbahesh, Rimmelzwaan and Saletti. This is an open-access article distributed under the terms of the Creative Commons Attribution License (CC BY). The use, distribution or reproduction in other forums is permitted, provided the original author(s) and the copyright owner(s) are credited and that the original publication in this journal is cited, in accordance with accepted academic practice. No use, distribution or reproduction is permitted which does not comply with these terms. 